\title{
Population studies of tree-defoliating insects in Canada: a century in review
}

\author{
R.C. Johns, ${ }^{1}$ L. Flaherty, D. Carleton, S. Edwards, A. Morrison, E. Owens
}

\begin{abstract}
Our review highlights research during the past century focussed on the population ecology of outbreak-prone insect defoliators in Canadian forests. Based on reports from national and provincial surveys that began in the 1930s, there have been at least 106 insect defoliators reported to outbreak, most of which are native Lepidoptera, Hymenoptera (sawflies), or Coleoptera (in order of frequency from most to least). Studies comparing life-history traits of outbreak versus non-outbreak species to better understand why certain species are more outbreak-prone indicate several traits especially common among outbreak species, including egg clustering and aggregative larval feeding. There have been at least 50 time-series studies examining the spatiotemporal population behaviour of 12 major defoliator species. These studies provide evidence for both regular periodicity and spatial synchrony of outbreaks for most major species. Life-table studies seeking to understand the agents causing populations to fluctuate have been carried out for at least seven outbreak species, with the majority identifying natural enemies (usually parasitoids) as the major driver of outbreak collapse. Our review concludes with several case studies highlighting the impact and historical underpinnings of population studies for major defoliator species and a discussion of potential avenues for future research.
\end{abstract}

\section{Introduction}

Forests host an enormous diversity of defoliating insects, most of which persist at low population levels, nibbling at foliage but rarely causing conspicuous damage. A comparatively small percentage of species are prone to occasional outbreaks, attaining population levels that can strip single trees or entire forests of foliage. Although taxonomically rare, outbreak defoliators have for more than 60 years served as the model system of choice for developing theories of animal population dynamics (Cappuccino 1995). This bias may reflect several factors. Outbreak defoliators tend to be conspicuous and easy to sample, attack economically and sociopolitically important plants, and undergo immense, but not unbounded, fluctuations in population density. Moreover, there are numerous long-term time series of population levels for most major outbreak species, many of which offer tantalising hints of cyclic dynamics at local, regional, or

Received 20 November 2014. Accepted 14 September 2015. First published online 25 January 2016.

R.C. Johns, ${ }^{1}$ Natural Resources Canada, Canadian Forest Service-Atlantic Forestry Centre, Fredericton, New Brunswick, E3B 5P7, Canada; and Population Ecology Group, Faculty of Forestry and Environmental Management, University of New Brunswick, Fredericton, New Brunswick, E3B 5A3, Canada

L. Flaherty, Population Ecology Group, Faculty of Forestry and Environmental Management, University of New Brunswick, Fredericton, New Brunswick, E3B 5A3, Canada; and Department of Biological Sciences, MacEwan University, Edmonton, Alberta, T5J 4S2, Canada

D. Carleton, Population Ecology Group, Faculty of Forestry and Environmental Management, University of New Brunswick, Fredericton, New Brunswick, E3B 5A3, Canada; and New Brunswick Department of Natural Resources, Fredericton, New Brunswick, E3B P7, Canada

S. Edwards, Population Ecology Group, Faculty of Forestry and Environmental Management, University of New Brunswick, Fredericton, New Brunswick, E3B 5A3, Canada

A. Morrison, E. Owens, Population Ecology Group, Faculty of Forestry and Environmental Management, University of New Brunswick, Fredericton, New Brunswick, E3B 5A3, Canada; and Forest Protection Limited, Fredericton International Airport, 2502 Route 102 Highway Lincoln, New Brunswick, E3B 7E6, Canada

${ }^{1}$ Corresponding author (e-mail: rob.johns@ canada.ca).

Langor, D.W. and Alfaro, R.I. (eds.) Forest Entomology in Canada: Celebrating a Century of Science Excellence doi: $10.4039 /$ tce. 2015.69 
continental scales. Much of what we know about animal population dynamics can be traced to pioneering studies involving outbreak defoliators.

Our understanding of defoliator population dynamics has progressed significantly during the past century, aided by technological and analytical advances and guided by vibrant debate (reviewed by Turchin 1995; Liebhold and Kamata 2000). Debates have centred largely on fundamental questions concerning the underlying nature of outbreak population behaviour. For instance, why are some defoliators prone to outbreak while the majority are not? Do outbreaks occur with a regular periodicity and are they spatially synchronised? What are the main ecological processes driving outbreak cycles? Or, as Royama (1992) put it simply, "Why do animal populations fluctuate as they do?" Our review summarises the efforts of researchers during the past century to address these questions for tree-defoliating insects in Canada. We begin with a basic synopsis of the outbreak defoliators reported in Canadian forests during the past century. Next, we examine studies that have addressed the above questions, focussing on broad historical trends, the frequency of various research approaches used, and some general patterns in the conclusions drawn from these studies. Finally, we feature selected case studies to highlight the history and scope of population research in Canada and to illustrate some of the key insights provided from the different approaches.

\section{Scope and data sources}

Our summary of outbreak defoliators was derived primarily from annual Forest Insect and Disease Survey (FIDS) reports (1936-1995). Broadly defined, a "defoliator" might include any insect species that consumes the leafy, photosynthetic tissue of its host plant. However, for the purposes of our review, we focus on defoliators that feed externally on leaves and exclude those that feed from within leaves (e.g., leaf miners and gall formers). This is in part because few miners or gallers are considered to be major outbreak pests in Canada, but is also because the ecological processes governing population fluctuations of these groups tend to differ from those of external feeders (Price 1997). It should be noted also that our reference to so-called "outbreak species" encompasses a significant breadth of population behaviours ranging from brief, local bouts of intense defoliation to multi-year, landscape-level epidemics. Not all species included would fall under other more rigorous definitions of "outbreak species" (e.g., Hunter 1995); however, for completeness, we have opted to include all species reported to have caused "severe" defoliation at any scale in the FIDS reports.

Details on population studies were gathered from available reference sources, including Google Scholar (dates unknown), Biological Abstracts (1989-2014), and various books and review articles that have explored the population dynamics of outbreak insects (e.g., Cappuccino and Price 1995; Barbosa et al. 2012). As key words, we used "defoliator" combined with each of "time series", "chronology", "periodicity", "spatial synchrony", "life table", "key factor", or "density dependent", and selected articles (and references therein) that involved research in Canadian forests, regardless of the nationalities of author or journal. Although this search was not exhaustive, it should provide a fair representation of Canadian population ecology research.

\section{Outbreak defoliators in Canada}

At least 106 species of defoliators have been reported to outbreak in Canadian forests during the past century, all from the orders Lepidoptera, Hymenoptera (sawflies), and Coleoptera (beetles) (from most to fewest species; Fig. 1A, Table 1). However, if we were to restrict this list to include only those that have significant long-term economic or ecological impacts on Canadian forests, less than half a dozen species would remain, with most being Lepidoptera (e.g., tent caterpillar (Malacosoma disstria Hübner; Lasiocampidae), spruce budworm (Choristoneura fumiferana Clemens; Tortricidae), western spruce budworm (Choristoneura freemani Rozowski; Tortricidae), hemlock looper (Lambdina fiscellaria Guenée; Geometridae)) or Hymenoptera (larch sawfly (Pristiphora erichisonii Hartig; Tenthredinidae)). Most outbreaking species in Canada are native (86\%), although it is notable that nearly $25 \%$ of all outbreaking sawfly species are exotics from Europe (Fig. 1A). Whereas most lepidopteran (74\%) and all beetle outbreaks occur on deciduous hosts, sawfly outbreaks occur mainly on conifers $(70 \%$, including both evergreen and deciduous conifers) (Fig. 1B). Most outbreak defoliator species are univoltine 
Fig. 1. The number of defoliator species in the orders Lepidoptera, Hymenoptera, and Coleoptera reported to have caused severe defoliation in Canada on at least one occasion between 1936 and 2014. Defoliators are categorised with respect to (A) native/invasive status, (B) host-type preference, and (C) voltinism.
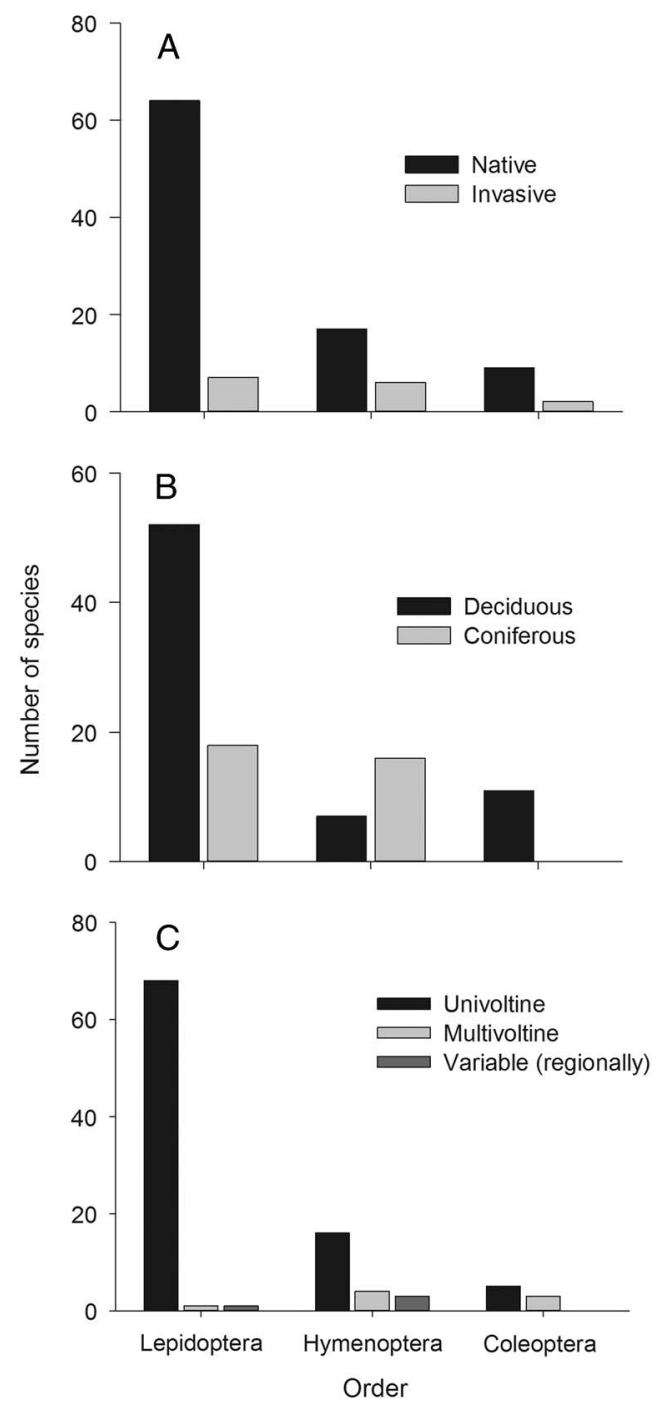

(i.e., have one generation per year), except for beetles, which generally have short generation times and are split equally between univoltine and bivoltine species (Fig. 1C).

\section{Population studies}

\section{Why are some species prone to outbreak?}

Comparative studies. It remains a great mystery why most insect defoliators persist at relatively low, stable population levels, but a small percentage, perhaps as little as $1-3 \%$, are prone to outbreaks (Faeth 1987; Hunter 1991, 1995). Comparative studies aim to shed light on this mystery by identifying ecological traits associated with the differing outbreak tendency between closely related species occupying similar habitats (Hunter 1991; Koricheva et al. 2012). One of the major challenges of this approach is that it requires substantial knowledge of basic life-history traits for both outbreak and non-outbreak species (e.g., size, fecundity, egg, and larval distribution, etc.). Although ample information is often available for outbreak species, rare or cryptic species are largely unstudied outside of taxonomy, and even basic traits remain unknown. A few researchers, however, have been able to cobble together enough information for certain groups to provide interesting insights on patterns of traits seemingly common among outbreaks species (reviewed in Koricheva et al. 2012).

In one such Canadian study of North American Lepidoptera on hardwoods, Hunter (1991) found numerous traits common (though not universal) among outbreak species, including spring feeding, polyphagy, overwintering as eggs, gregarious larvae, clustered eggs, high fecundity, large size, and strong defenses against natural enemies. In general, outbreak defoliators could be further delineated into one of two groups: (1) spring feeders that remain as eggs for most of the year and (2) summer feeders that feed gregariously (Hunter 1991). Subsequent analyses including European species detected similar trends and ruled out possible confounding effects of phylogeny (Hunter 1995). Although not Canadian in origin, similar studies for sawflies have noted that many outbreak-prone species have some of the same ecological traits as outbreaking Lepidoptera, in particular clustered egg lay and larval feeding (Haack and Mattson 1993; Larsson et al. 1993; Koricheva et al. 2012), as well as an unusually high outbreak tendency among species that prefer coniferous over deciduous hosts (Price et al. 2005). Although comparative analyses are not definitive in explaining why certain species have outbreak population dynamics, they do underscore potentially significant evolutionary and ecological trends that warrant further investigation (e.g., the adaptive significance of 
Table 1. Summary of outbreak tree defoliators in Canada derived from the Forest Insects and Disease Surveys (1936-1995), including common and Latin names, voltinism, primary host preference(s) during outbreak, and regional distribution of reported outbreaks within Canada.

\begin{tabular}{|c|c|c|c|c|}
\hline Order/family/common name & Species & Voltinism & Primary hosts during outbreak & $\begin{array}{l}\text { Regional distribution } \\
\text { of outbreaks }\end{array}$ \\
\hline \multicolumn{5}{|l|}{ Lepidoptera } \\
\hline \multicolumn{5}{|l|}{ Arctiidae } \\
\hline Fall webworm & Hyphantria cunea & Univoltine & Populus, Malus & $\mathrm{A}, \mathrm{E}, \mathrm{C}, \mathrm{W}$ \\
\hline Silverspotted tiger moth & Lophocampa argentata & Univoltine & Pseudotsuga & $\mathrm{W}$ \\
\hline \multicolumn{5}{|l|}{ Bucculatricidae } \\
\hline Birch skeletoniser & Bucculatrix canadensisella & Univoltine & Betula & $\mathrm{A}, \mathrm{E}, \mathrm{W}$ \\
\hline \multicolumn{5}{|l|}{ Coleophoridae } \\
\hline Larch casebearer $^{\dagger}$ & Coleophora laricella & Univoltine & Larix & $\mathrm{A}, \mathrm{E}, \mathrm{W}$ \\
\hline Birch casebearer $^{\dagger}$ & Coleophora serratella & Univoltine & Betula, Populus & $\mathrm{A}, \mathrm{E}$ \\
\hline \multicolumn{5}{|l|}{ Geometridae } \\
\hline Fall cankerworm & Alsophila pometaria & Univoltine & Fraxinus, Quercus, Acer & $\mathrm{A}, \mathrm{E}, \mathrm{C}, \mathrm{W}$ \\
\hline Elm spanworm & Ennomos subsignaria & Univoltine & Ulmus, Populus & $\mathrm{A}, \mathrm{E}$ \\
\hline Linden looper & Erannis tiliara & Univoltine & Pinus, Prunus, Populus* & $\mathrm{E}, \mathrm{C}, \mathrm{N}, \mathrm{W}$ \\
\hline Western winter moth & Erannis tiliara vancouverensis & Univoltine & Acer, Salix, Betula* & $\mathrm{W}$ \\
\hline Cherry scallop-shell moth & Hydria prunivorata & Univoltine & Prunus & $\mathrm{E}$ \\
\hline Pale winged grey & Iridopsis ephyraria & Univoltine & Tsuga & $\mathrm{A}, \mathrm{W}$ \\
\hline Lesser maple spanworm & Itame pustularia & Univoltine & Acer & $\mathrm{A}, \mathrm{E}$ \\
\hline Eastern hemlock looper & Lambdina fiscellaria fiscellaria & Univoltine & Abies, Tsuga & $\mathrm{A}, \mathrm{E}, \mathrm{W}$ \\
\hline Western hemlock looper & Lambdina fiscellaria lugubrosa & Univoltine & Abies, Tsuga & $\mathrm{W}$ \\
\hline Western oak looper & Lambdina fiscellaria somniaria & Univoltine & Quercus, Pseudotsuga & $\mathrm{W}$ \\
\hline Green larch looper & Macaria sexmaculata & Univoltine & Larix & $\mathrm{A}$ \\
\hline Western false hemlock looper & Nepytia freemani & Univoltine & Pseudotsuga & $\mathrm{W}$ \\
\hline Phantom hemlock looper & Nepytia phantasmaria & Univoltine & Tsuga & $\mathrm{W}$ \\
\hline Bruce spanworm & Operophtera bruceata & Univoltine & Salix, Populus & $\mathrm{A}, \mathrm{E}, \mathrm{C}, \mathrm{W}, \mathrm{N}$ \\
\hline Winter moth ${ }^{\dagger}$ & Operophtera brumata & Univoltine & Quercus, Populus, Betula* & $\mathrm{A}, \mathrm{W}$ \\
\hline Spring cankerworm & Paleacrita vernata & Univoltine & Fraxinus, Quercus, Ulmus & $\mathrm{A}, \mathrm{E}$ \\
\hline Spear-marked black moth & Rheumaptera hastata & Univoltine & Betula, Alnus & $\mathrm{E}, \mathrm{C}, \mathrm{W}, \mathrm{N}$ \\
\hline Gray spruce looper & Caripeta divisata & Univoltine & Tsuga, Larix, Abies* & $\mathrm{W}$ \\
\hline Spiny looper & Phigalia titea & Univoltine & Acer & $\mathrm{E}$ \\
\hline \multicolumn{5}{|l|}{ Incurvariidae } \\
\hline Maple leafcutter & Paraclemensia acerifoliella & Univoltine & Acer, Quercus & $\mathrm{E}$ \\
\hline \multicolumn{5}{|l|}{ Lasiocampidae } \\
\hline Eastern tent caterpillar & Malacosoma americanum & Univoltine & Prunus, Malus, Acer* & $\mathrm{A}, \mathrm{E}$ \\
\hline Western (northern) tent caterpillar & Malacosoma californicum pluviale & Univoltine & Malus, Populus, Prunus* & $\mathrm{E}, \mathrm{C}, \mathrm{W}$ \\
\hline Forest tent caterpillar & Malacosoma disstria & Univoltine & Populus, Fraxinus, Acer* & A, E, C, W \\
\hline
\end{tabular}




\section{Order/family/common name}

Prairie tent caterpillar

Lymantriidae

Brown-tail moth ${ }^{\dagger}$

Satin moth ${ }^{\dagger}$

Gypsy moth

Rusty tussock moth

Whitemarked tussock moth

Douglas-fir tussock moth

Noctuidae

Black army cutworm

Variable oak leaf caterpillar

Aspen twoleaf tier

Notodonitae

Saddled prominent

Redhumped oakworm

Orangehumped mapleworm

Walnut caterpillar moth

Nymphalidae

Mourning cloak butterfly

Oecophoridae

Oak leaftier

Pieridae

Pine white

Psychidae

Evergreen bagworm

Saturniidae

Green-striped mapleworm

Rosy-striped oakworm

Orange-striped oakworm

Cecropia moth

Northern pink-striped oakworm

Sphingidae

Ash sphinx

Hawk moth

Tortricidae

Western blackheaded budworm

Blackheaded budworm

\section{Species}

Malacosoma californicum lutescens

Euproctis chrysorrhoea

Leucoma salicis

Lymantria dispar

Orgyia antiqua

Orgyia leucostigma

Orygia pseudotsugata

\section{Actebia fennica}

Lochmaeus manteo

Enargia decolor

Heterocampa guttivitta

Symmerista canicosta

Symmerista leucitys

Datana integerrima

Nymphalis antiopa

Psilocorsis quercicella

Neophasia menapia

Thyridopteryx ephemeraeformis

Dryocampa rubicunda

Anisota virginiensis

Anisota senatoria

Hyalophora cecropia

Anisota virginiensis virginiensis

Ceratomia undulosa borealis

Sphingidae species

Acleris gloverana

Acleris variana
Voltinism

Univoltine

Univoltine

Univoltine

Univoltine

Univoltine

Univoltine

Univoltine

Univoltine

Univoltine

Univoltine

Univoltine

Univoltine

Univoltine

Univoltine

Both

Univoltine

Univoltine

Univoltine

Univoltine

.

Univoltine

Univoltine

Univoltine

Multivoltine

Univoltine

Univoltine
Primary hosts during outbreak

Prunus, Rosa

Malus, Quercus, Amelanchier* Populus, Salix

Quercus, Betula, Malus*

Pinus, Picea, Alnus*

Abies, Pinus, Picea*

Pseudotsugata, Abies, Picea

Abies, Picea, Cyanococcus*

Quercus

Populus

Fagus, Betula, Acer*

Quercus, Acer, Fagus

Acer, Fagus

Juglans, Carya

Salix, Ulmus, Populus*

Quercus

Pinus, Pseudotsuga, Abies, Picea

Thuja, Juniperus, Pinus

Acer

Quercus

Quercus

Acer, Prunus, Betula*

Quercus

Fraxinus

Fraxinus

Regional distribution of outbreaks

C

A, E

A, E, W

A, E, W

A, E, C, W, N

A, E

W

A, E, W

A, E

A

A, E

A, E, C

A

E, C

A, C, W, N

A, E

W

E

A, E

E

E

A, E

C

Abies, Tsuga

Abies, Picea 
Order/family/common name

Uglynest caterpillar

Two-year-cycle budworm

Large aspen tortix

Eastern spruce budworm

Western spruce budworm

Jack pine budworm

Oblique-banded leaf roller

Oak leafshredder

Three-lined leafroller moth

Early aspen leafroller

Bare-patched leafroller

Spotted aspen leafroller

Maple leafroller

Spruce budmoth

Larch budmoth

Birch-aspen leafroller

Oak leafroller

European pine shoot moth

Larch needleworm

Hymenoptera

Diprionidae

Introduced pine sawfly ${ }^{\dagger}$

European spruce sawfly

Balsam fir sawfly

Redheaded pine sawfly

Red pine sawfly

White pine sawfly

Jack pine sawfly

Jack pine sawfly

Redheaded jack pine sawfly

European pine sawfly

Swaine jack pine sawfly

Hemlock sawfly

Conifer sawfly

Tenthredinidae

Birch sawfly

Dusky birch sawfly

Striped alder sawfly

Species

Voltinism

Archips cerasivorana

Choristoneura biennis

Choristoneura conflictana

Choristoneura fumiferana

Choristoneura freemani

Choristoneura pinus pinus

Choristoneura rosaceana

Croesia semipurpurana

Pandemis limitata

Pseudexentera oregonana

Pseudexentera spoliana

Pseudosciaphila duplex

Sparganothis acerivorana

Zeiraphera canadensis

Zeiraphera diniana

Epinotia solandriana

Archips semiferana

Rhyacionia buoliana

Zeiraphera improbana

Diprion similis

Gilpinia hercyniae

Neodiprion abietis

Neodiprion lecontei

Neodiprion nanulus nanulus

Neodiprion pinetum

Neodiprion pratti banksianae

Neodiprion pratti paradoxicus

Neodiprion rugifrons

Neodiprion sertifer

Neodiprion swainei

Neodiprion tsugae

Neodiprion nanulus contortae

Arge pectoralis

Craesus latitarsus

Hemichroa crocea

Univoltine

Univoltine

Univoltine

Univoltine

Univoltine

Univoltine

Univoltine

Univoltine

Univoltine

Univoltine

Univoltine

Univoltine

Univoltine

Univoltine

Univoltine

Univoltine

Univoltine

Univoltine

Bivoltine

Both

Univoltine

Univoltine

Univoltine

Univoltine

Univoltine

Univoltine

Univoltine

Univoltine

Univoltine

Univoltine

Univoltine
Primary hosts during outbreak

Prunus, Populus, Crataegus*

Picea, Abies

Populus

Picea, Abies

Abies, Pseudotsuga, Picea

Pinus

Malus, Alnus, Rosa*

Quercus

Malus, Alnus, Rosa*

Populus

Quercus

Populus, Betula, Salix

Acer

Picea

Larix

Betula

Quercus

Pinus

Larix

A, E, C, W

C, W, N

A, E, C, W, N

A, E, C, W, N

W

A, E, C, W

E, W

A, E

W

E, C, W, N

A

A

A, E

A, E, C, W

W

W

A

A

W, C

Pinus

Picea

Abies, Picea

Pinus

Pinus

Pinus

Pinus

Pinus

Pinus

Pinus

Tsuga, Abies

Pinus

E, C

A, E, C, N

A, E, C

E

A, E, C

A, C

E

E, E

A, E, C, W

A, E

A, E, W

W

Betula

Betula

Alnus, Salix, Betula
A, E, C, W

A

A, E, W 
Table 1. Continued

\begin{tabular}{|c|c|c|c|c|}
\hline Order/family/common name & Species & Voltinism & Primary hosts during outbreak & $\begin{array}{l}\text { Regional distribution } \\
\text { of outbreaks }\end{array}$ \\
\hline Sawfly & Nematus limbatus & Bivoltine & Salix, Populus & $\mathrm{A}, \mathrm{E}$ \\
\hline Plum webspinning sawfly & Neurotoma inconspicua & Univoltine & Prunus & A \\
\hline Yellowheaded spruce sawfly & Pikonema alaskensis & Univoltine & Picea & $\mathrm{A}, \mathrm{E}, \mathrm{C}, \mathrm{W}, \mathrm{N}$ \\
\hline Larch sawfly & Pristiphora erichsonii & Univoltine & Larix & $A, E, C, W, N$ \\
\hline Mountain ash sawfly ${ }^{\dagger}$ & Pristiphora geniculata & Both & Sorbus & A, E, C \\
\hline Wooly alder sawfly ${ }^{\frac{T}{T}}$ & Eriocampa ovata & Bivoltine & Alnus & $\mathrm{E}, \mathrm{W}$ \\
\hline Willow sawfly & Nematus oligospilus & Univoltine & Salix, Populus & $\mathrm{A}, \mathrm{E}$ \\
\hline \multicolumn{5}{|l|}{ Pamphiliidae } \\
\hline Pine false webworm ${ }^{\dagger}$ & Acantholyda erythrocephala & Univoltine & Pinus & $\mathrm{E}, \mathrm{W}$ \\
\hline \multicolumn{5}{|l|}{ Coleoptera } \\
\hline \multicolumn{5}{|l|}{ Chrysomelidae } \\
\hline Cottonwood leaf beetle & Chrysomela scripta fabricius & Multivoltine & Populus, Alnus & $\mathrm{C}, \mathrm{W}, \mathrm{N}$ \\
\hline American aspen beetle & Gonioctena americana & Univoltine & Populus & $\mathrm{C}, \mathrm{W}, \mathrm{N}$ \\
\hline Pacific willow leaf beetle & Tricholochmaea decora carbo & & Salix & $\mathrm{W}$ \\
\hline Gray willow leaf beetle & Tricholochmaea decora decora & & Salix, Populus & $\mathrm{E}, \mathrm{C}, \mathrm{W}, \mathrm{N}$ \\
\hline Elm leaf beetle ${ }^{\dagger}$ & Xanthogaleruca luteola & Multivoltine & Ulmus & A, E \\
\hline White aspen leaf beetle & Chrysomela crotchi & Univoltine & Populus & $\mathrm{E}, \mathrm{C}, \mathrm{W}, \mathrm{N}$ \\
\hline Willow-and-poplar leaf beetle & Chrysomela falsa & . & Salix & $\mathrm{A}, \mathrm{W}$ \\
\hline Western/prairie willow leaf beetle & Galerucella decora & & Salix, Populus & $\mathrm{C}$ \\
\hline Imported willow leaf beetle ${ }^{\dagger}$ & Plagiodera versicolora & Multivoltine & Salix, Populus & A \\
\hline Alder flea beetle & Macrohaltica ambiens & Univoltine & Alnus & A, E, W \\
\hline
\end{tabular}

* Species reported to feed on $>3$ host genera. The genera listed are the most common attacked during outbreaks.

Invasive species.

A, Atlantic (Newfoundland and Labrador, Prince Edward Island, Nova Scotia, New Brunswick); E, eastern (Québec, Ontario), C, central (Manitoba, Saskatchewan), W, western (Alberta, British Columbia),

$\mathrm{N}$, northern territories (Nunavut, Northwest Territories, Yukon). 
clustered egg lay and gregarious larval feeding for outbreak species, reviewed in Cappuccino et al. 1995).

\section{Are outbreaks periodic and spatially synchronised?}

Time-series studies. One of the major goals in the study of insect population dynamics is to understand the spatiotemporal nature of population fluctuations. In particular, population behaviours such as periodicity (i.e., statistically significant regularity in population cycles) and spatial synchrony (i.e., similar density fluctuations among spatially disjunct populations) have caught the interest of many population ecologists due at least in part to their seeming ubiquity among most major outbreak defoliator species (Liebhold and Kamata 2000). However, elucidating these spatial and temporal trends with any statistical rigor can be challenging, as it requires relatively long-term data sets on insect density, ideally covering multiple outbreaks and the full outbreak range. Most of the major outbreak defoliators outbreak at 10-35-year intervals and thus require decades or even centuries of time-series data for there to be any conclusive analysis of outbreak trends.

In Canada, there have been at least 50 time-series studies for 12 defoliator species examining (at least peripherally) the periodicity and/or spatial synchrony of outbreaks (Table 2). The frequency of time-series studies has increased during the past 60 years (Fig. 2), with almost half of all studies focussing on spruce budworm. These time series have been built from various proxies for population density (Fig. 3). Anecdotal reports from historical documents formed the basis of some of the earliest published time series in Canada, which were for fall webworm and tent caterpillar (Baird 1917; Sippell 1962). However, time series constructed from the tree rings of ancient timbers are by far the most common source of long-term time series, taking advantage of the tendency of trees to suffer diminished radial growth during periods of intense herbivory (Fig. 3). A smaller number of studies have used annual estimates of defoliation from aerial or ground surveys (Fig. 3). Although defoliation time series are typically shorter than those from tree rings (Fig. 3), they tend to encompass relatively large, contiguous areas, making them highly amenable to spatial statistical analyses (Table 2). Direct measures of defoliator populations (e.g., eggs or tents) clearly provide the most precise estimates of population density but are laborious to collect, short in duration, and perhaps because of this the least common source of time-series data (Fig. 3). At least one study has used macrofossils (ancient frass) to detect spruce budworm outbreaks nearly 7000 years in the past, although trends were too crude to provide much information on population behaviour (Simard et al. 2006).

Most time-series studies in Canada provide indications of regular, albeit imperfect periodicity for most major outbreak species. Only larch sawfly has been consistently cited as lacking any clear regularity in its cycles (Table 2). In studies with time series from multiple sites, spatial synchrony in population trends is often evident, at least in the sense that outbreak cycles in one site or region appear to fluctuate in a similar manner to those in seemingly disjoined locations (Table 2). However, the scale at which spatial synchrony occurs varies significantly among studies, sometimes occurring among fairly local sites (e.g., Moreau 2006) and in other instances occurring at regional (e.g., Cooke et al. 2012) or transcontinental scales (e.g., Williams and Liebhold 2000). It is important to note that relatively few Canadian studies have carried out statistical analyses to detect either periodicity or spatial synchrony, or to examine some of the more subtle mathematical properties of the outbreak cycles (e.g., harmonic cycles, quasi-periodicity, density dependence, limit cycles, chaos, etc.). This lack of analysis, coupled with the tendency of time-series studies to focus on species that characteristically undergo periodic, spatially synchronous outbreaks, may exaggerate the ubiquity of these traits among outbreak defoliator species (Liebhold and Kamata 2000).

\section{What are the main ecological processes that drive outbreak cycles?}

Life-table studies. Life tables were originally developed as part of actuarial and demographic studies of human populations, but were later adapted to study the processes driving insect outbreaks (Morris and Miller 1954; Harcourt 1960). Whereas time series tend to focus on broad-scale or long-term population trends based 
Fig. 2. The number of peer-reviewed articles per decade using time series of population density (or proxies) to assess periodicity and/or spatial synchrony in populations of outbreaking tree defoliators.

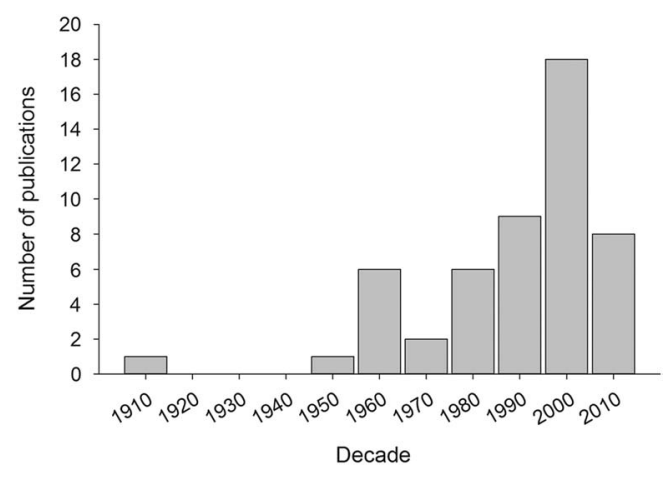

Fig. 3. The number and average length of time-series data sets assembled between 1936 and 2014 from different proxies of population density, including anecdotal reports, tree rings (i.e., dendrochronology), defoliation, and insect density.

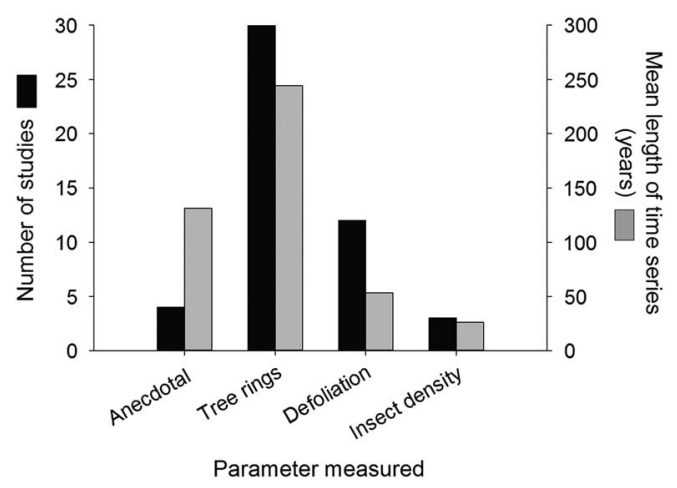

on annual estimates of population density, life tables provide a more meticulous and systematic accounting across multiple life stages to identify those factors most responsible for changes in population density (Morris and Miller 1954; Harcourt 1960). Researchers in Canada have contributed significantly to the arduous task of collecting life-table data for many major outbreaking insects, as well as to the development of analytical techniques for detecting possible regulatory agents (i.e., those acting in a density-dependent manner) (Morris 1963a; Royama 1992).

For Canadian forest defoliators, there have been at least 12 life-table studies for seven defoliator species (Table 3). The majority of these studies have been carried out during the past 55 years (Fig. 4), and nearly half of them are for conifer-feeding budworms (Table 3 ). Whereas the duration of these life tables ranges between three to 35 years, all of these studies tend to focus on dynamics in only a few sites and cover only a portion of an outbreak cycle, and in most cases focus on populations in decline (Table 3). Only three life-table studies have assessed populations at low density (Table 3) and no study to date has captured the transition of a population from low to high density. In general, many factors contribute to generational mortality as populations decline; however, in most studies the primary driver of population collapse and subsequent maintenance of populations at low density was natural enemies (usually parasitoids) (Table 3). A few studies also provide evidence of host-plant feedbacks that may in some cases cause or contribute to population decline (Table 3 ). It should be noted that half of the studies cited have drawn their conclusions from key factor (also known as k-factor) analyses (Morris 1959). This analytical approach, however, has been abandoned owing to various statistical and logical issues (Royama 1996) in favor of alternative approaches (Royama 1992). At least for spruce budworm, this shift in analytical techniques led to a new interpretation of the main factors driving outbreak cycles, from what was essentially the same data (Table 3: Morris 1963a versus Royama 1984).

Experiments. Experimental approaches are also commonly used to study the processes influencing insect outbreak cycles (Myers and Rothman 1995). The scope and complexity of such experiments can vary significantly, ranging from fairly targeted studies assessing relationships among herbivores, host plants, and natural enemies, to more complex field experiments where the researchers have sought to manipulate outbreak cycles through preventing outbreaks, creating outbreaks, or manipulating the processes hypothesised to drive changes in population density (reviewed in Myers and Rothman 1995). In some cases, the theoretical advancements derived from experiments have been profound. For example, Holling's (1959) experimental work on European pine sawfly-predator interactions was the cornerstone of his work on functional 
Table 2. Summary of time-series studies for outbreaking defoliators in Canadian forests during the past century assessing the periodicity and/or spatial synchrony of population cycles.

\begin{tabular}{|c|c|c|c|c|c|c|c|}
\hline \multirow[b]{2}{*}{ Defoliator } & \multirow[b]{2}{*}{$\begin{array}{c}\text { Years of time series } \\
\text { (total) }\end{array}$} & \multirow[b]{2}{*}{$\begin{array}{l}\text { Parameters } \\
\text { measured }\end{array}$} & \multirow[b]{2}{*}{$\begin{array}{l}\text { Location of } \\
\text { study }\end{array}$} & \multirow[b]{2}{*}{$\begin{array}{l}\text { Number of } \\
\text { outbreak }\end{array}$} & \multicolumn{2}{|c|}{ Population behaviours } & \multirow[b]{2}{*}{ Source } \\
\hline & & & & & $\begin{array}{c}\text { Periodicity } \\
\text { (years)* }^{*}\end{array}$ & $\begin{array}{c}\text { Spatial } \\
\text { synchrony }^{\dagger}\end{array}$ & \\
\hline \multicolumn{8}{|l|}{ Lepidoptera } \\
\hline \multirow{2}{*}{ Fall webworm } & 1770-1917 (147) & Anecdotal & NA & 7 & $7-14$ & Yes & Baird (1917) \\
\hline & 1827-1961 (138) & Anecdotal, tents & $\mathrm{NB}, \mathrm{NS}$ & 14 & $8-16$ & Yes & Morris (1964) \\
\hline Western tent caterpillar & $1976-1999$ (23) & Tents, eggs & $\mathrm{BC}$ & $2-3$ & $6-11$ & Yes & Myers (2000) \\
\hline \multirow[t]{7}{*}{ Forest tent caterpillar } & $1770-1917(147)$ & Anecdotal & NA & 9 & $7-14$ & Yes & Baird (1917) \\
\hline & $1923-1953(30)$ & Defoliation & $\mathrm{MB}, \mathrm{SK}$ & 5 & $6-16$ & - & Hildahl and Reeks (1960) \\
\hline & 1867-1960 (93) & $\begin{array}{l}\text { Anecdotal, } \\
\text { defoliation }\end{array}$ & $\mathrm{ON}$ & 9 & $6-14$ & - & Sippell (1962) \\
\hline & 1948-1988 (41) & Defoliation & $\mathrm{ON}$ & 4 & $10-15$ & Yes & Daniel and Myers (1995) \\
\hline & $1938-2002$ (64) & Defoliation & QC & 6 & $9-14$ & Yes & $\begin{array}{l}\text { Cooke and Lorenzetti } \\
\text { (2006) }\end{array}$ \\
\hline & 1800-2002 (202) & Tree rings & SK & 4 & $21-22$ & - & Sutton and Tardif (2007) \\
\hline & $1938-2002(64)$ & Defoliation & $\mathrm{ON}, \mathrm{QC}$ & 8 & 9-14 & Yes & Cooke et al. (2012) \\
\hline Douglas fir tussock moth & $1916-1983$ (67) & Defoliation & $\mathrm{BC}$ & 8 & $\sim 9$ & Yes & Shepherd et al. (1988) \\
\hline \multirow{16}{*}{ Spruce budworm } & $1802-1950(148)$ & Tree rings & $\mathrm{ON}$ & 3 & $\sim 93$ & - & Blais (1954) \\
\hline & $1870-1956(86)$ & Tree rings & $\mathrm{QC}$ & $3-4$ & $35-73$ & - & Blais (1961) \\
\hline & $1680-1961(281)$ & Tree rings & $\mathrm{QC}$ & 6 & $26-76$ & - & Blais (1965) \\
\hline & 1780-1978 (198) & Tree rings & QC & 4 & $27-127$ & - & Blais (1981a) \\
\hline & $1761-1972(211)$ & Tree rings & QC & 3 & $28-127$ & - & Blais (1981b) \\
\hline & $1704-1972(268)$ & Tree rings & QC & 11 & $24-75$ & Yes & Blais (1983) \\
\hline & $1750-1980(230)$ & Tree rings & $\mathrm{NB}, \mathrm{QC}$ & $7-8$ & 29-35 & - & Royama (1984) \\
\hline & $1690-1985$ (195) & Tree rings & $\mathrm{QC}$ & 4 & $26-76$ & - & Morin and Laprise (1990) \\
\hline & $1780-1990(210)$ & Tree rings & QC & 4 & $11-109$ & - & Morin et al. (1993) \\
\hline & $1672-1954(282)$ & Tree rings & QC & $5-6$ & $24-57$ & - & Krause (1997) \\
\hline & 1859-1989 (130) & Tree rings & $\mathrm{QC}$ & 4 & $23-38$ & - & Filion et al. (1998) \\
\hline & $1941-1996(55)$ & Defoliation & ON & 2 & 31-37 & Yes & Candau et al. (1998) \\
\hline & 1900-1994 (94) & Tree rings & $\mathrm{QC}$ & 3 & $28-33$ & - & Krause and Morin (1999) \\
\hline & $1945-1988$ (43) & Defoliation & NA & 1 & - & Yes & $\begin{array}{l}\text { Williams and Liebhold } \\
\text { (2000) }\end{array}$ \\
\hline & $1817-1992(175)$ & Tree rings & $\mathrm{BC}$ & 6 & $\sim 26$ & No & Burleigh et al. (2002) \\
\hline & $1850-1996(146)$ & Tree rings & $\mathrm{QC}$ & 6 & $25-38$ & Yes & Jardon et al. (2003) \\
\hline
\end{tabular}




\begin{tabular}{|c|c|c|c|c|c|c|c|}
\hline \multirow[b]{2}{*}{ Defoliator } & \multirow[b]{2}{*}{$\begin{array}{l}\text { Years of time series } \\
\text { (total) }\end{array}$} & \multirow[b]{2}{*}{$\begin{array}{l}\text { Parameters } \\
\text { measured }\end{array}$} & \multirow[b]{2}{*}{$\begin{array}{l}\text { Location of } \\
\text { study }\end{array}$} & \multirow[b]{2}{*}{$\begin{array}{l}\text { Number of } \\
\text { outbreak }\end{array}$} & \multicolumn{2}{|c|}{ Population behaviours } & \multirow[b]{2}{*}{ Source } \\
\hline & & & & & $\begin{array}{l}\text { Periodicity } \\
\text { (years)* }^{*}\end{array}$ & $\begin{array}{c}\text { Spatial } \\
\text { synchrony }^{\dagger}\end{array}$ & \\
\hline & 1513-2002 (489) & Tree rings & QC & 11 & $32-65$ & Yes & $\begin{array}{l}\text { Boulanger and Arsenault } \\
\text { (2004) }\end{array}$ \\
\hline & $1859-2000(141)$ & Tree rings & QC & 3 & $23-38$ & - & Lemieux and Filion (2004) \\
\hline & 1952-1999 (47) & Eggs & NB & 2 & - & Yes & Royama et al. (2005) \\
\hline & $1820-2000(180)$ & Tree rings & QC & $5-6$ & $20-35$ & Yes & Bouchard et al. (2006) \\
\hline & 6020BC-2005 (8240) & Fossilized frass & QC & $>2$ & - & - & Simard et al. (2006) \\
\hline & 1840-2000 (160) & Tree rings & QC & 4 & $30-35$ & Yes & $\begin{array}{l}\text { Bouchard and Pothier } \\
\text { (2010) }\end{array}$ \\
\hline & $1754-2005(251)$ & Tree rings & QC & 6 & $30-40$ & - & Sonia et al. (2011) \\
\hline & $1551-1995(444)$ & Tree rings & QC & 12 & $28-50$ & Yes & Boulanger et al. (2012) \\
\hline \multirow[t]{3}{*}{ Western spruce budworm } & $1600-2000(400)$ & Tree rings & $\mathrm{BC}$ & 8 & $30-43$ & - & Campbell et al. (2006) \\
\hline & $1500-2012(516)$ & Tree rings & $\mathrm{BC}$ & 15 & 21-35 & - & Alfaro et al. (2014) \\
\hline & $1576-2011(435)$ & Tree rings & $\mathrm{BC}$ & 12 & $16-32$ & Yes & Axelson et al. (2015) \\
\hline $\begin{array}{l}\text { Western blackheaded } \\
\text { budworm }\end{array}$ & 1940-1998 (58) & Defoliation & $\mathrm{BC}$ & 5 & $12-16$ & - & Shepherd and Gray (2001) \\
\hline Jack pine budworm & 1937-1987 (50) & Defoliation & MB, SK & 7 & $\sim \mathbf{1 0}$ & - & Volney (1988) \\
\hline \multirow[t]{2}{*}{ Two-year cycle budworm } & 1720-1997 (277) & Tree rings & $\mathrm{BC}$ & 4 & 24-39 & Yes & Zhang and Alfaro (2002) \\
\hline & $1670-2000(330)$ & Tree rings & $\mathrm{BC}$ & 7 & $30-46$ & - & Parish and Antos (2002) \\
\hline \multicolumn{8}{|l|}{ Hymenoptera } \\
\hline Balsam fir sawfly & 1944-2004 (60) & Defoliation & NL & 7 & $5-15$ & - & Moreau (2006) \\
\hline \multirow[t]{6}{*}{ Larch sawfly } & 1949-1959 (10) & Tree rings & SK, MB & 3 & $14-16$ & - & Nairn et al. (1962) \\
\hline & 1596-1987 (391) & Tree rings & $\mathrm{QC}$ & 2 & 35 & Yes & Arquillière et al. (1990) \\
\hline & $1682-1989$ (300) & Tree rings & QC & 10 & $6-49$ & - & Jardon et al. (1994) \\
\hline & $1858-1996(138)$ & Tree rings & QC & 6 & $10-25$ & - & Girardin et al. (2001) \\
\hline & $1800-2000(200)$ & Tree rings & MT & 5 & $12-56$ & - & Girardin et al. (2005) \\
\hline & $1700-2000(300)$ & Tree rings & NL & 8 & $14-77$ & Yes & $\begin{array}{l}\text { Nishimura and Laroque } \\
\text { (2010) }\end{array}$ \\
\hline Swaine jack pine sawfly & 1956-1970 (14) & Defoliation & QC & 2 & $\sim 8$ & Yes & McLeod (1972) \\
\hline
\end{tabular}

* Numbers represent the range of periods observed. Bold emphasis indicates that statistical analyses were carried out to support observed trends.

${ }^{\dagger}$ Bold emphasis indicates that statistical analyses were carried out to support observed trends.

ON, Ontario; QC, Québec; MB, Manitoba; BC, British Columbia; SK, Saskatechewan; AB, Alberta; NS, Nova Scotia; NB, New Brunswick; NL, Newfoundland and Labrador; NA, North America;

USA, United States of America 
Table 3. Summary of life-table studies for outbreaking defoliators in Canadian forests during the past century examining the potential factors driving changes in population density during outbreaks.

\begin{tabular}{|c|c|c|c|c|c|c|}
\hline Defoliator & Years of study (total) & Stage of outbreak* & Study location & Factors examined $* *$ & Analyses $^{\dagger}$ & Sources \\
\hline \multicolumn{7}{|l|}{ Lepidoptera } \\
\hline \multirow[t]{3}{*}{ Winter moth } & 1954-1962 (9) & Decline & NS & Par, Pred, F & $\mathrm{k}$ & Embree (1965) \\
\hline & $1982-1986(5)$ & Rise - decline & $\mathrm{BC}, \mathrm{NS}$ & Par, Pred & $\mathrm{r}$ & Roland (1988) \\
\hline & 1982-1990 (8) & Decline - low density & $\mathrm{BC}$ & Par, Pred & $\mathrm{k}$ & Roland (1994) \\
\hline \multirow[t]{4}{*}{ Spruce budworm } & $1945-1959(24)$ & Rise - decline & NB & Par, Pred, DI, W, F & $\mathrm{k}$ & Morris (1963a) \\
\hline & 1949-1959 (10) & Low density & NB & Par & $\mathrm{k}$ & Miller and Renault (1976) \\
\hline & 1945-1980 (35) & Rise - decline & NB & Par, Pred, W, F & $\mathrm{r}$ & Royama (1984) \\
\hline & 1983-1996 (15) & Rise - decline & ON, QC & Par, F & $\mathrm{r}$ & Régnière and Nealis (2007) \\
\hline Spruce budmoth & 1988-1992 (5) & Decline & NB & $\mathbf{F}$ & $\mathrm{r}$ & Ostaff and Quiring (2000) \\
\hline $\begin{array}{l}\text { Western blackheaded } \\
\text { budworm }\end{array}$ & $1970-1973(4)$ & Decline & $\mathrm{BC}$ & $\mathbf{F}$ & $\mathrm{k}$ & Shepherd and Gray (2001) \\
\hline \multicolumn{7}{|l|}{ Hymenoptera } \\
\hline European spruce sawfly & $1937-1963$ (26) & Decline - low density & NB & Par, Pred, DI, W & $\mathrm{k}$ & Neilson and Morris (1964) \\
\hline Balsam fir sawfly & 2000-2002 (3) & Rise - decline & $\mathrm{NL}$ & Par, DI, F & $\mathrm{r}$ & Moreau (2004) \\
\hline Larch sawfly & 1956-1972 (17) & Rise - decline & MB & Par, Pred, W & $\mathrm{k}$ & Ives (1976) \\
\hline
\end{tabular}


Fig. 4. The number of peer-reviewed articles per decade using life-table data to identify possible regulatory agents (i.e., those acting in a density dependent manner) for outbreak tree defoliators.

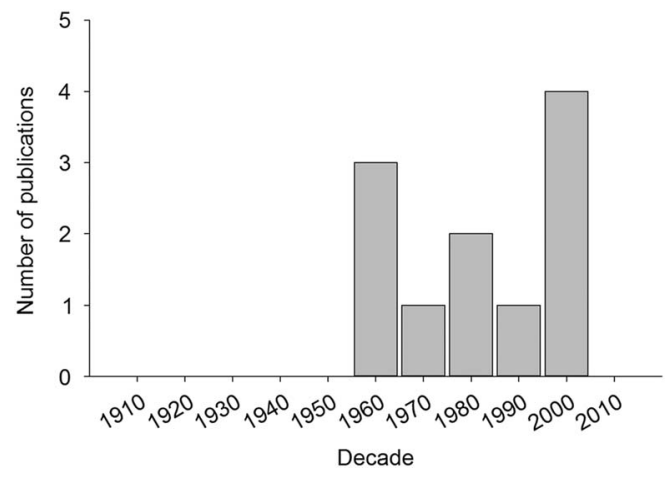

responses, a fundamental concept in animal population dynamics, and may be one of the most cited papers in The Canadian Entomologist's history. Although we have not summarised the myriad experiments that have been carried out using outbreak forest defoliators, we have provided many noteworthy examples in the following section.

\section{Case studies}

In the following section, we feature case studies blending together the population research for some of the most-studied lepidopteran and sawfly defoliators in Canada, focussing in particular on those that have been examined through combinations of time-series, life-table, and experimental approaches. These case studies allow us to discuss details on impact, provide some historical context, and illustrate how knowledge gained through this work has helped to inform the development of management tactics and strategies to limit defoliator impact. Notably, we will not discuss here the extensive literature for conifer-feeding budworms (i.e., Choristoneura Lederer (Lepidoptera: Tortricidae) and Acleris Hübner (Lepidoptera: Tortricidae) species), which are covered in Nealis (2015).

\section{Lepidoptera}

Fall webworm, Hyphantria cunea Drury (Lepidoptera: Arctiidae). Fall webworm is a tent-forming defoliator, native to North America that is fairly innocuous compared with many of Canada's most destructive defoliating pests.
Outbreaks tend to have a limited impact and centre on open-grown or roadside speckled alder (Alnus incana (Linnaeus) Moench; Betulaceae) (Morris 1971). Despite not being considered a major defoliator, the fall webworm was the focus of the earliest insect population studies ever published in Canada (Baird 1917; Tothill 1922). To early entomologists, fall webworm was an intriguing model system, in part because it was easy to identify and sample, but also because it underwent relatively modest population fluctuations that seemed indicative of strong regulatory mechanisms (Tothill 1922; Morris and Fulton 1970a). It was expected that building an understanding of the processes regulating fall webworm populations might provide insight into the processes driving outbreaks of some of the more injurious defoliators of the time, such as spruce budworm (Morris 1963a) and European spruce sawfly (Neilson and Morris 1964).

The first population ecology research for fall webworm, and the first of its kind for a defoliator in Canada, was a crude time series that reconstructed outbreak history using anecdotal records extending back to the late 1700s (Baird 1917). Tothill (1922) complemented this work with a more detailed eight-year time series collected by sighting tents from a slow-moving vehicle in the area surrounding Fredericton, New Brunswick, Canada. Morris (1964) revisited these old data and expanded upon them using FIDS data from Nova Scotia to Saskatchewan. Collectively, these approaches suggested an outbreak periodicity of $8-16$ years and some regional spatial synchrony, although these data were not analysed statistically (Table 2). Tothill (1922) also published one of the first examples of life-table data in Canada using fall webworm, although the information it provided was quite basic by today's standards. Research on fall webworm increased significantly between 1957 and 1973 thanks to a series of field and laboratory studies in New Brunswick and Nova Scotia carried out by R.F. Morris and collaborators. Although starvation sometimes reduced colony survival at peak density, it was primarily parasitism and predation that were thought to regulate populations (Morris 1972a, 1972b, 1976a). Interactions with natural enemies, however, were greatly complicated by factors such as larval size (Morris 1963b), annual variability in parasitoid egg encapsulation by 
caterpillars (Morris 1976b), colony size (Morris 1972a, 1976c), and hyperparasitism (Morris 1976d). Survival also varied annually and regionally in response to variations in weather and the associated capacity of larvae to accumulate sufficient degree-days to enter diapause (Morris and Fulton 1970a, 1970b).

In the end, the intended simulation model was never built from the pieces provided by these experiments, and fall webworm continues to be a fairly inconsequential pest of roadside alder. However, Morris' work has provided an invaluable basis for comparison for researchers in other countries where fall webworm has become an important invasive pest of fruit crops (Hidaka 1977).

Winter moth, Operophtera brumata Linnaeus (Lepidoptera: Geometridae). Winter moth is an invasive defoliator of a variety of deciduous trees that was introduced from Europe into Nova Scotia in the mid 1930s (Hawboldt and Cuming 1950) and again onto Vancouver Island, British Columbia around 1972 (Gillespie et al. 1978). Much of the economic losses associated with defoliation by winter moth occurred on shade and ornamental trees in cities and towns, and occasionally in fruit orchards (Cuming 1961). In natural forests, red oak, Quercus rubra var. borealis (Michxaux) Farwell (Fagaceae), appeared to sustain particularly high defoliation, with potential indirect effects on the susceptibility of valuable white pine understorey to white pine weevil, Pissodes strobe (Peck) (Coleoptera: Curculionidae) (Embree 1965). In Nova Scotia and later in Vancouver, two European parasitoids of winter moth, Cyzenis albicans (Fallén) (Diptera: Tachinidae) and Agrypon flaveolatum (Gravenhorst) (Hymenoptera: Ichneumonidae), were released as part of a classical biological control programme (Embree 1965). Within just a few years of release, winter moth populations collapsed, and there have been no large-scale outbreaks since (Embree 1965; Roland 1988).

Population trends in Nova Scotia have been examined in time series covering the peak to decline (Embree 1965) and the subsequent maintenance of winter moth populations at low densities following the introduction of parasitoids (Embree 1991). Life-table studies have also been carried out for winter moth in Nova Scotia (Embree 1965), British Columbia (Roland 1988,
1994), and its native range in Europe (Varley and Gradwell 1968). There has been some debate whether the introduced parasitoids were solely or only indirectly the cause of winter moth decline. Whereas Embree $(1965,1991)$ argued for the importance of the introduced parasitoids to population collapse and subsequent regulation at low density, Roland (1988) attributed the population decline to pupal predation associated with larval ground beetles (Coleoptera: Carabidae), with parasitism adding significant mortality but playing a more indirect, non-regulatory role. Interestingly, the European parasitoids that were introduced have very little impact on winter moth populations in its native European range, where pupal mortality associated with predation is the main regulatory factor (Varley and Gradwell 1968). Roland (1994) continued his life-table studies on Vancouver Island for six years after the decline of winter moth to determine what processes were keeping populations low. Although parasitism still caused significant mortality, pupal predators were the main factor regulating populations at low density through a direct density-dependent response to pupal density (Roland 1994). Winter moth populations have since remained relatively low in Canadian oak forests, although small outbreaks do still sometimes occur in fruit orchards (Embree 1991).

This strategy of classical biological control for winter moth, which was largely validated through the aforementioned population studies, continues to be the primary approach for managing new winter moth introductions (e.g., Donahue 2015).

Forest tent caterpillar, Malacosoma disstria Hübner (Lepidoptera: Lasiocampidae). Forest tent caterpillar outbreaks occur across Canada and can cause major defoliation to a variety of broadleaf hosts. Outbreaks have been noted at least anecdotally in North America as far back as 1790 (Baird 1917). The colonial distribution of eggs and larvae make this group highly convenient for population studies, and few defoliators in Canada have been studied more intensively.

Whether forest tent caterpillar outbreaks are periodic or irregular has been the subject of extensive analyses and debate. The earliest work by Baird (1917) examining historical trends suggested a periodicity of 7-14 years (Table 2). More recent time-series analyses have taken 
advantage of long-term defoliation surveys and suggest an outbreak periodicity of 6-16 years, with the most commonly reported average being 10 years (Table 2). Time-series analyses by Cooke and Lorenzetti (2006) indicate that population oscillations are "characterized by strong secondorder negative feedback, suggesting regulation by lagged density-dependent processes". Outbreaks appear to occur with some degree of spatial synchrony, although the degree of synchronisation may vary regionally (Hildahl and Reeks 1960; Sippell 1962; Cooke and Lorenzetti 2006; Cooke et al. 2012).

Early studies of forest tent caterpillar dynamics attributed increases or declines in population density primarily to early-spring and overwintering temperatures (Wellington 1952; Blais et al. 1955; Witter and Kulman 1972; Ives 1973). However, when this hypothesis was tested explicitly by Daniel and Myers (1995), using records from Ontario, the authors were unable to detect any relationship between interannual variation in defoliation (a proxy for population density) and either winter or spring temperatures. They did, however, report that defoliation was less severe in areas with the coldest winter temperatures, and suggested that extreme weather conditions may play a role in synchronising populations (e.g., "Moran effects", Myers 1998). More recent studies suggest that winter temperatures may be important determinants of outbreak duration in northern climates (Cooke and Roland 2003), albeit secondary to the effects of forest fragmentation (Roland et al. 1998; Cooke and Roland 2000). Aside from weather influences, outbreak collapse may be caused by a nucleopolyhedrovirus (Clark 1958; Stairs 1966; Bird 1969; Ebling and Kaupp 1995) and to a lesser extent a parasitic fly, Sarcophaga aldrichi Parker (Sippell 1962).

As mentioned above, there is also strong evidence that forest tent caterpillar dynamics are influenced by forestry and land-development practices, with the degree of forest fragmentation being a major determinant of outbreak duration (Roland 1993; Roland et al. 1998; Cooke and Roland 2000; but see Wood et al. 2010). Roland (2005) also found that populations exhibited more rapid cycles in contiguous than in fragmented forests and concluded that forest structure had a significant impact on the lagged density-dependent processes that drive outbreak cycles, in particular through its effects on natural enemies (Rothman and Roland 1998; Roland 2005). For example, forest tent caterpillar larvae at the edge of fragmented forests may have reduced virus transmission (Roland and Kaupp 1995) and lower mortality associated with at least some parasitoids (Roland and Taylor 1997; Roth et al. 2006).

Since the earliest work by Baird (1917), forest tent caterpillar has provided an ideal model system for developing and testing theories of population dynamics for outbreaking defoliators. The practical implications of this long-term study include the revelations of how forestry practices, such as those that lead to increasing forest fragmentation, may exacerbate the intensity of damage caused by some outbreak-prone pests.

\section{Hymenoptera (sawflies)}

European spruce sawfly, Diprion hercyniae Hartig (Hymenoptera: Diprionidae). European spruce sawfly is an invasive defoliator of mature foliage in spruce (Picea Dietrich; Pinaceae) that was first discovered on the Gaspé Peninsula of eastern Québec in 1930 (Neilson and Morris 1964). Incidentally, it was this discovery that has been largely credited with hastening the establishment of the long-standing Forest Insect and Disease Survey programme in Canada (Wallace and Cunningham 1995). By 1938, an outbreak was raging throughout much of the Maritimes and New England and prompted the introduction of a comprehensive classical biological control programme from 1933 through 1945 (Reeks 1953). By 1936, however, a highly infectious virus (a nucleopolyhedrovirus) was also observed in reared larvae and, by 1939, had spread through the population. It was speculated that the virus was vectored into the population by some of the introduced parasitoids (Balch and Bird 1944; Bird and Elgee 1957). By 1945, the sawfly outbreak had collapsed and has not since reached the widespread, epidemic population levels seen during that outbreak.

There are limited long-term population studies of European spruce sawfly in Canada and only a handful of experiments, most of which focus on the mechanisms of virus transmission (Neilson and Elgee 1968). However, there is at least one detailed 25-year population study that was conducted in New Brunswick from 1938 through 1961, which spanned the peak to collapse of the 
outbreak, as well as the following 18 years when population densities remained low (Neilson and Morris 1964). This study provided a rare opportunity to study not only the factors driving population collapse, but also the processes that maintained the population at low levels after collapse. Virus and weather appeared to be the "key factors" driving population collapse, but a combination of parasitism and cocoon predation was largely responsible for regulating populations at low levels after the collapse (Neilson and Morris 1964). Complementary experiments where the virus was introduced into populations with no previous infection further confirmed the efficacy of the virus (Bird and Elgee 1957). An incidental treatment of dichlorodiphenyltrichloroethane (DDT) to the study sites from 1960 through 1962, which was actually meant to suppress a local spruce budworm outbreak, essentially eradicated the local population.

The biological control work for European spruce sawfly led to the discovery and ultimate establishment of the virus into Canada, and the population studies that followed confirmed the efficacy of this agent for suppressing outbreaks. Although there have been a few local spikes in populations reported in the past few decades, there have been no more significant regional outbreaks since the virus was introduced (Forest Insects and Disease Survey 1936-1995).

Swaine jack pine sawfly, Neodiprion swainei (Middleton) (Hymenoptera: Diprionidae). The Swaine jack pine sawfly is a major but infrequent native pest of mature jack pine, Pinus banksiana Lambert (Pinaceae), which has been studied primarily in Ontario and Québec. As of the 1970s, there were approximately two million ha of jack pine stands that were considered susceptible to sawfly outbreaks (McLeod 1970). At the time, jack pine was a cheap and easily harvested resource for the pulp and paper industry, and the extensive tree mortality that often followed outbreaks was cause for significant concern (McLeod 1970). Between 1940 and 1970, outbreaks of jack pine sawfly had a periodicity of around eight years and may have been synchronised regionally (McLeod 1972), although no sufficiently long time series have been published to confirm this periodicity. Although outbreaks are often intense, leading to complete tree-wide defoliation, they are also typically short, often lasting only two to five years (McLeod 1970, 1972). Surveys indicated, however, that when outbreaks occurred, populations rose quickly. During an outbreak in Roberval, Québec during the 1960s, for example, populations rose at a rate of 2.6-fold per year (McLeod 1970). At such high growth rates, populations reached tree-killing densities within as few as four years, and peak larval densities rose as high as 9.8 million per ha (McLeod 1970).

Although there are no published time series or life tables for jack pine sawfly, there has been some experimental work attempting to disrupt cycles through the use of insecticides. An experiment carried out in Québec from 1962 to 1967 found that a single, direct insecticide (phosphamidon) application diminished population densities and disrupted the cycling of populations relative to other populations in the area for at least five years following spray; however, populations in surrounding areas that suffered only a light insecticide application quickly regained normal cycling (McLeod 1972). The rebound of the lightly treated populations was associated primarily with recovery of larval survival rates rather than with immigration of egg-laying females from nearby populations (McLeod 1972). This study suggested that the processes synchronising jack pine sawfly population cycles over broad spatial areas are relatively robust, but that they can be overwhelmed by strong perturbations.

There remain many gaps in the study of jack pine sawfly population dynamics, in particular a conspicuous lack of long-term time-series and life-table studies. However, McLeod's (1972) experimental work is noteworthy as it provides a rare example of a study that has taken advantage of insecticide applications to better understand the population behaviour of an outbreak herbivore.

Larch sawfly, Pristiphora erichsonii Hartig (Hymenoptera: Tenthredinidae). Larch sawfly is a Holarctic defoliator with a distribution that essentially follows that of larch, Larix Miller (Pinaceae), throughout the northern hemisphere. Major outbreaks in Canada have been credited with killing large swaths of larch since the late 19th century (Fyles 1892; Ives and Muldrew 1984). A striking example is provided by Fyles (1892), who reported a township in Québec that 
lost virtually all of its merchantable tamarack (Larix laricina (Du Roi) Koch) in a 260-ha stand to a larch sawfly outbreak. Similarly intense outbreaks of larch sawfly have been reported repeatedly across Canada over the past century (Ives and Muldrew 1984).

Time-series studies of larch sawfly have focussed largely on establishing that larch sawfly is a native defoliator to Canada (Ives and Muldrew 1984; Nishimura and Laroque 2010). The first recorded outbreak in North America occurred along the eastern seaboard in 1880 and then appeared to spread north and west - this outbreak was speculated to represent the unintentional introduction of larch sawfly to North America from Europe (Fyles 1892; Hewitt 1912; Ives and Muldrew 1984). However, evidence from tree-ring growth patterns in tamarack from Québec and Labrador indicates that larch sawfly outbreaks have a long history in Canada that far predates the 1880s (Jardon et al. 1994; Nishimura and Laroque 2010). Although the periodicity of outbreaks is highly variable (i.e., between 14 and 77 years), there is some observational evidence of regional synchronicity in outbreaks (Table 2).

Early studies indicated that there were many factors causing sawfly mortality in high-density populations, including starvation (Heron 1955; Ives 1963), storms and flooding (Lejeune 1955; Graham 1956; Ives 1976), larval and cocoon predation (Buckner 1958, 1959; Buckner and Turnock 1965), and some limited parasitism (Turnock and Muldrew 1971, 1972; Ives 1976). A life-table study in southeastern Manitoba from 1956 to 1972 concluded that mammal predation of cocoons was the key factor driving population cycles, although periodic flooding events also appeared to contribute to population collapse (Ives 1976). To mitigate an apparent paucity of mortality agents, an extensive programme of classical biological control was implemented and eventually resulted in the successful establishment of two European parasitoids, Olesicampe benefactor Hinz and Mesoleius tenthredinis Morley (Hymenoptera: Ichneumonidae) (Hewitt 1917; Turnock and Muldrew 1971). Parasitism by $O$. benefactor in particular has been an important factor in keeping populations low, although its effectiveness may be offset to some extent by a hyperparasitoid, Mesochorus dimidiatus Holmgren (Hymenoptera: Ichneumonidae) (Ives 1976).
Population studies were instrumental in confirming larch sawfly was a native pest to Canada with a long history of outbreak. No large-scale outbreaks of larch sawfly have occurred in recent decades, which may be related to the extensive biological control work that has been carried out; however, although studies were able to show the successful establishment of $O$. benefactor, it has yet to be confirmed that this parasitoid is responsible for keeping populations low over the long term.

Balsam fir sawfly, Neodiprion abietis (Harris) (Hymenoptera: Diprionidae). Balsam fir sawfly is a major native defoliating pest of mainly balsam fir, Abies balsamea (Linnaeus) Miller (Pinaceae). Although this sawfly has a transcontinental distribution in North America (Ross 1955; Wallace and Cunningham 1995), outbreaks are most common in Atlantic Canada (Martineau 1985). In the late 1990s, an outbreak in central Newfoundland became a source of major concern for the local pulp and paper industries due to its unusually high severity, geographical extent, and longevity (Moreau 2006), prompting nearly a decade of intensive research to explain the cause of the outbreak and to develop control strategies to reduce damage.

Outbreaks are typically localised but can be quite severe, sometimes resulting in almost complete tree defoliation (current-year foliage is rarely eaten); however, such outbreaks are also usually short in duration, rarely lasting more than three to six years (Cunningham 1984; Moreau 2006). In western Newfoundland, historical time-series records of defoliation spanning over 60 years indicated an outbreak periodicity of about six years, with evidence of oscillatory population behaviour (Moreau 2006). Moreau (2006) noted that increases in outbreak severity and duration corresponded to increased use of precommercial thinning, a forestry practice that involves removing stems to reduce competition between neighbouring trees. Contemporaneous studies in the same region supported this hypothesis, showing that at peak outbreak, egg density and defoliation due to larval feeding were higher in thinned than in unthinned stands (Ostaff et al. 2006).

To determine why precommercial thinning increased the intensity of outbreaks, a life-table study was conducted in western Newfoundland from 1999 to 2002 (Moreau 2004). Although the 
number of generations sampled within individual sites was relatively low (i.e., three to four generations), a range of sites was selected to represent late-rising, peaking, and collapsing populations, thereby providing a fair snapshot of the broader outbreak cycle in thinned and unthinned stands. In general, rising populations were characterised by relatively high fecundity, female-biased sex ratios, high late-instar survival, and immigration, all of which translated into enhanced intergenerational recruitment rates (Moreau 2004). In contrast, the collapse of populations was driven primarily by increased infection rates by a virus (nucleopolyhedrovirus, NeabNPV), which caused extreme larval mortality and moderate prepupal and pupal mortality (Moreau 2004; Moreau et al. 2006a). Mortality associated with a generalist parasitoid, Mesopolobus verditer (Norton) (Hymenoptera: Pteromalidae), also contributed to population declines in some sites. Although the duration of the outbreak peak to collapse was similar between thinned and unthinned stands (i.e., two to four years), the amplitude of population fluctuations and associated defoliation was higher in thinned stands, owing at least in part to higher larval survival (Moreau 2004; Moreau et al. 2006a; Ostaff et al. 2006). Complementary experiments showed that precommercial thinning altered the relative and overall impact of bottom-up (host plant quality) versus top-down (natural enemies) forces on larval survival (Moreau et al. 2006b) and reduced the negative influence of previous defoliation on foliage nutritional quality and associated larval performance (Moreau and Quiring 2011).

Overall, these studies drew attention to the potentially negative influence of commercial forestry practices on defoliator outbreaks, but also provided the basis for developing a useful biological control agent (the virus) that has since become part of the integrated pest management programme for balsam fir sawfly (Moreau et al. 2005).

\section{Conclusions}

Our review underscores the tremendous efforts of researchers to address the fundamental questions driving population ecology research on outbreak defoliators in Canada. Comparative studies, although few in number, have provided interesting insights on the key traits possessed by outbreak species and lacking in typically non-outbreak species. There have been a fair number of time series and life-table data sets collected for the major outbreak species in Canada, particularly given the significant cost and commitment required to collect these data. Qualitative examination of time-series data provides strong indications of both regular periodicity and spatial synchrony in outbreaks of major defoliators (Table 2). Life-table studies highlight the particular importance of top-down trophic interactions for driving the decline and maintenance of populations at low density (Table 3). Putting aside for now the important theoretical advancements that we have highlighted in this review, we will conclude by addressing questions of a more practical nature: after more than 100 years of research and countless millions spent, what has the study of defoliator population dynamics achieved? And, what work still lies ahead?

What have we achieved? Broadly speaking, we would highlight several practical advancements arising from Canadian population research for outbreak defoliators. Much of the research to date draws attention to the predominance of natural enemies in regulating populations, although recent work has reintroduced the potential importance of host quality as an indirect factor influencing population decline (e.g., Régnière and Nealis 2007; Moreau and Quiring 2011). This insight has contributed to several striking examples of successful biological control for invasive species (e.g., winter moth and European spruce sawfly) and to some extent native pests (e.g., larch sawfly and balsam fir sawfly). Moreover, insights into the temporal and spatial nature of defoliator outbreaks have come to form the basis of pest management strategies, which is perhaps best illustrated in the long-standing debate over whether to manage spruce budworm outbreaks through a "foliage protection" versus "population control" strategy (Royama 1984; Régnière et al. 2012). Another important contribution of this work has been confirmation of the importance of forestry practices in affecting the behaviour and structure of defoliator populations (e.g., forest fragmentation, Roland 1993, 2005; precommercial thinning, Moreau et al. 2006b; forest composition, Eveleigh et al. 2007). Understanding the role forest composition and structure play in shaping outbreaks provides a 
basis for selecting silvicultural practices aimed at reducing forest susceptibility to defoliator damage.

What lies ahead? There is no shortage of work to be done on outbreak defoliators, whether that be through revisiting older data sets, collecting more data, or harnessing new, innovative technologies. As we discussed previously, qualitative analyses of time-series data could be buttressed in the future with deeper quantitative analyses (e.g., Cooke et al. 2012). In a similar vein, there may be value in revisiting some past life-table data sets to see what further insights could be drawn from more advanced analyses (e.g., Morris 1963a versus Royama 1984). Technological advances during the past decades, in particular with respect to genomics (Cusson 2008), are becoming an invaluable component of population, community, and landscape ecology involving outbreak defoliators, with many remarkable and sometimes unexpected revelations (e.g., Smith et al. 2011; James et al. 2014). As our review highlights, there is also a paucity of studies of defoliator populations during the low density or rising phases of outbreak. This represents a significant knowledge gap and a potentially rich avenue for future investigation (e.g., Régnière et al. 2012). Finally, it is becoming increasingly evident that studies of outbreak defoliator population dynamics are going to need to be considered in the context of a changing climate (Pureswaran et al. 2015). Not only is climate change likely to alter the intensity, distribution, and extent of common outbreak species (Gray 2013; Pureswaran et al. 2015), it also has the potential to promote outbreaks among species that have rarely or never been known to outbreak in the past.

As a final point, our review makes clear the benefits of long-term, persistent research in terms of our understanding of insect outbreaks for some of the major defoliator species in Canada (e.g., budworms and tent caterpillars). However, the trends and processes driving these outbreaks are not necessarily representative of all species that have been reported to outbreak at one time or another. Indeed, the apparently cyclic and synchronous nature of most of the half-dozen major outbreaks species in Canada are at odds with the majority of species, most of which undergo relatively sporadic and localised outbreaks. One particularly striking omission is the paucity of research on outbreaking coleopteran defoliators, although this is probably due to the relative infrequency, brevity, and limited distribution of outbreaks, as well as the low economic value of the host trees attacked (i.e., mainly Populus Linnaeus; Salicaceae and Salix Linnaeus; Salicaceae). Studies of these and other defoliators that undergo more local or sporadic outbreaks (or that never outbreak at all) could provide a deeper perspective on the overarching ecological question of why animal populations fluctuate as they do.

\section{Acknowledgements}

The authors thank H. Blaquiere and Z. Fitch for helping to gather materials for the large defoliator table, and G. Pohl and H. Goulet for providing estimates of the total number of defoliators in Canada. We thank R. Alfaro, S. Heard, D. Langor, C. MacQuarrie, E. Moise, Z. Sylvain, D. Quiring, and several anonymous reviewers for comments and discussions on earlier versions of the manuscript.

\section{References}

Alfaro, R.I., Berg, J., and Axelson, J. 2014. Periodicity of western spruce budworm in southern British Columbia, Canada. Forest Ecology and Management, 315: 72-79.

Arquillière, S., Filion, L., Gajewski, L., and Cloutier, C. 1990. A dendroecological analysis of eastern larch (Larix larcina) in subarctic Quebec. Canadian Journal of Forest Research, 20: 1312-1319.

Axelson, J.M., Smith, D.J., and Alfaro, R.I. 2015. Multicentury reconstruction of western spruce budworm outbreaks in central British Columbia, Canada. Forest Ecology and Management, 335: 235-248.

Baird, A.B. 1917. A historical account of the forest tent caterpillar and of the fall webworm in North America. Annual Report of the Entomological Society of Ontario, 47: 73-87.

Balch, R.E. and Bird, F.T. 1944. A disease of the European spruce sawfly, Gilpinia hercyniae (Htg.) and its place in natural control. Science Agriculture, 25: 65-80.

Barbosa, P., Letourneau, D.K., and Agrawal, A.A. 2012. Insect outbreaks revisted. Princeton University Press, Princeton, New Jersey, United States of America.

Bird, F.T. 1969. Infection and mortality of spruce budworm, Choristoneura funiferana, and forest tent caterpillar, Malacosoma disstria, caused by nuclear and cytoplasmic polyhedrosis viruses. The Canadian Entomologist, 101: 1269-1285. 
Bird, F.T. and Elgee, D.E. 1957. A virus disease and introduced parasites as factors controlling the European spruce sawfly, Diprion hercyniae (Htg.), in central New Brunswick. The Canadian Entomologist, 89: 371-378.

Blais, J.R. 1954. The recurrence of spruce budworm infestations in the past century in the Lac Seul area in northwestern Ontario. Ecology, 35: 62-71.

Blais, J.R. 1961. Spruce budworm outbreaks in the lower St. Lawrence and Gaspé regions. The Forestry Chronicle, 37: 192-202.

Blais, J.R. 1965. Spruce budworm outbreaks in the past three centuries in the Laurentide Park, Quebec. Forest Science, 11: 130-138.

Blais, J.R. 1981a. Mortality of balsam fir and white spruce following a spruce budworm in the Ottawa River watershed in Quebec. Canadian Journal of Forest Research, 11: 620-629.

Blais, J.R. 1981b. Recurrence of spruce budworm outbreaks for two hundred years in western Quebec. The Forestry Chronicle, 57: 273-275.

Blais, J.R. 1983. Trends in the frequency, extent, and severity of spruce budworm outbreaks in eastern Canada. Canadian Journal of Forestry Research, 13: 539-547.

Blais, J.R., Prentice, R., Sippell, W.L., and Wallace, D. 1955. Effects of weather on forest tent caterpillar Malacosoma disstria Hbn. in central Canada in the spring of 1953. The Canadian Entomologist, 87: $1-8$.

Bouchard, M., Kneeshaw, D., and Bergeron, Y. 2006. Forest dynamics after successive spruce budworm outbreaks in mixedwood forests. Ecology, 87: 2319-2329.

Bouchard, M. and Pothier, M. 2010. Spatiotemporal variability in tree and stand mortality caused by spruce budworm outbreaks in eastern Quebec. Canadian Journal of Forest Research, 40: 86-94.

Boulanger, Y. and Arsenault, D. 2004. Spruce budworm outbreaks in eastern Quebec over the last 450 years. Canadian Journal of Forest Research, 34: 1035-1043.

Boulanger, Y., Arsenault, D., Morin, H., Jardon, Y., Bertrand, P., and Dagneau, C. 2012. Dendrochronological reconstruction of spruce budworm (Choristoneura fumiferana) outbreaks in southern Quebec for the last 400 years. Canadian Journal of Forest Research, 42: 1264-1276.

Buckner, C.H. 1958. Mammalian predators of the larch sawfly in eastern Manitoba. Tenth International Congress of Entomology, 4: 353-361.

Buckner, C.H. 1959. Mortality of cocoons of the larch sawfly, Pristiphora erichsonii (Htg.), in relation to distance from small mammal tunnels. The Canadian Entomologist, 91: 535-542.

Buckner, C.H. and Turnock, W.J. 1965. Avian predation on the larch sawfly, Pristiphora erichsonii (Htg.) (Hymenoptera: Tenthredinidae). Journal of Ecology, 46: 233-236.
Burleigh, J.S., Alfaro, R.I., Borden, J.H., and Taylor, S. 2002. Historical and spatial characteristics of spruce budworm Choristoneura fumiferana (Clem.) (Lepidoptera: Tortricidae) outbreaks in northeastern British Columbia. Forest Ecology and Management, 168: 301-309.

Campbell, R., Smith, D.J., and Arsenault, A. 2006. Multicentury history of western spruce budworm outbreaks in interior Douglas fir forests near Kamloops, British Columbia. Canadian Journal of Forest Research, 36: 1758-1769.

Candau, J.N., Flemming, R.A., and Hopkin, A. 1998. Spatiotemporal patterns of large-scale defoliation caused by the spruce budworm in Ontario since 1941. Canadian Journal of Forest Research, 28: 1733-1741.

Cappuccino, N. 1995. Novel approaches to the study of population dynamics. In Population dynamics: new approaches and synthesis. Edited by N. Cappuccino and P.W. Price. Academic Press, San Diego, California, United States of America. Pp. 3-16.

Cappuccino, N., Damman, H., and Dubuc, J.F. 1995. Spatial behavior and temporal dynamics of outbreak and nonoutbreak species. In Population dynamics: new approaches and synthesis. Edited by N. Cappuccino and P.W. Price. Academic Press, San Diego, California, United States of America. Pp. 65-82.

Cappuccino, N. and Price, P.W. 1995. Population dynamics: new approaches and synthesis. Academic Press, San Diego, California, United States of America.

Clark, E.C. 1958. Ecology of the polyhedroses of tent caterpillars. Ecology, 39: 132-139.

Cooke, B.J. and Lorenzetti, F. 2006. The dynamics of forest tent caterpillar outbreaks in Quebec, Canada. Forest Ecology and Management, 226: 110-121.

Cooke, B.J., MacQuarrie, C.J.K., and Lorenzetti, F. 2012. The dynamics of forest tent caterpillar outbreaks across east-central Canada. Ecography, 35: 422-435.

Cooke, B.J. and Roland, J. 2000. Spatial analysis of large-scale patterns of forest tent caterpillar outbreaks. Ecoscience, 7: 410-422.

Cooke, B.J. and Roland, J. 2003. The effect of winter temperatures on forest tent caterpillar egg survival and population dynamics in northern climates. Environmental Entomology, 32: 299-311.

Cuming, F.G. 1961. The distribution, life history, and economic importance of the winter moth, Operophtera brumata (L.) (Lepidoptera: Geometridae) in Nova Scotia. The Canadian Entomologist, 93: 135-142.

Cunningham, J.C. 1984. Neodiprion abietis (Harris), balsam fir sawfly (Hymenoptera: Diprionidae). In Biological control programs against insects and weeds in Canada. Edited by J.S. Kelleherand and M.A. Hulme. Commonwealth Agricultural Bureaux, Slough, United Kingdom. Pp. 1969-1980.

Cusson, M. 2008. The molecular biology toolbox and its use in basic and applied insect science. BioScience, 58: 691-700. 
Daniel, C. and Myers, J. 1995. Climate and outbreaks of the forest tent caterpillar. Ecography, 18: 353-362.

Donahue, C. 2015. Parasitic flies harnessed to fight winter moth [online]. Available from http://www. maine.gov/dacf/about/news/news.shtml?id=644110 [accessed 20 July 2015].

Ebling, P.M. and Kaupp, W.J. 1995. Differentiation and comparative activity of six isolates of a nuclear polyhedrosis virus from the forest tent caterpillar, Malacosoma disstria, Hubner. Journal of Invertebrate Pathology, 66: 198-200.

Embree, D.G. 1965. The population of the winter moth in Nova Scotia, 1954-1962. Memoirs of the Entomological Society of Canada, 46: 1-57.

Embree, D.G. 1991. The winter moth Operophtera brumata in eastern Canada, 1962-1988. Forest Ecology and Management, 39: 47-54.

Eveleigh, E.S., McCann, K.S., McCarthy, P.C., Pollock, S.J., Lucarotti, C.J., Morin, B., et al. 2007. Fluctuations in density of an outbreak species drive diversity cascades in food webs. Proceedings of the National Academy of Sciences of the United States of America, 104: 16976-16981.

Faeth, S.H. 1987. Community structure and folivorous insect outbreaks: the roles of vertical and horizontal interactions. In Insect outbreaks. Edited by P. Barbosa and J.C. Schultz. Academic Press, New York, New York, United States of America. Pp. 135-171.

Filion, L., Payette, S., Delwaide, A., and Bhiry, N. 1998. Insect defoliators as major disturbance factors in the high-altitude balsam fir forest of Mount Mégantic, southern Quebec. Canadian Journal of Forest Research, 28: 1832-1842.

Forest Insects and Disease Survey. 1936-1995. Annual report. Natural Resources Canada, Canadian Forestry Service, Ottawa, Ontario, Canada.

Fyles, T.W. 1892. Nematus erichsonii: a retrospect. Annual Report, Entomological Society of Ontario, 22: 28-30.

Gillespie, D.R., Finlayson, T., Tonks, N.V., and Ross, D.A. 1978. Occurrence of the winter moth, Operophtera brumata (Lepidoptera: Geometridae), on southern Vancouver Island, British Columbia. The Canadian Entomologist, 110: 223-224.

Girardin, M.P., Berglund, E., Tardif, J.C., and Monson, K. 2005. Radial growth of tamarack (Larix laricina) in the Churchill area, Manitoba, Canada, in relation to climate and larch sawfly (Pristiphora erichisonii) herbivory. Arctic, Antarctic, and Alpine Research, 37: 206-217.

Girardin, M.P., Tardif, J., and Bergeron, Y. 2001. Radial growth analysis of Larix laricina from the Lake Duparquet area, Québec, in relation to climate and larch sawfly outbreaks. Ecoscience, 8: 127-138.

Graham, S.A. 1956. The larch sawfly in the lake states. Forestry Science, 2: 132-160.
Gray, D.R. 2013. The influence of forest composition and climate on outbreak characteristics of spruce budworm in eastern Canada. Canadian Journal of Forest Research, 43: 1181-1195.

Haack, R.A. and Mattson, W. 1993. Life history patterns among North American tree-feeding sawflies. In Sawfly life history adaptions to woody plants. Edited by M.R. Wagner and K.F. Raffa. Academic Press, Boca Raton, Florida, United States of America. Pp. 503-545.

Harcourt, D.G. 1960. Distribution of the immature stages of the diamond-black moth, Plutella macilipennis (Curt.), on cabbage. The Canadian Entomologist, 93: 820-831.

Hawboldt, L.S. and Cuming, F.G. 1950. Cankerworms and European winter moth in Nova Scotia. Forest Insect Investigations, Bi-Monthly Progress Report, 6: $1-2$.

Heron, R.J. 1955. Studies on the starvation of last-instar larvae of the larch sawfly, Pristiphora erichsonii (Htg.) (Hymenoptera: Tenthredinidae). The Canadian Entomologist, 87: 417-427.

Hewitt, C.G. 1912. The larch sawfly (Nematus erichsonii). Division of Entomology Bulletin 10, 2nd series. Canadian Department of Agriculture, Ottawa, Ontario, Canada.

Hewitt, C.G. 1917. Report of the Dominion Entomologist for the year ending March 31, 1917. Canadian Department of Agriculture, Ottawa, Ontario, Canada.

Hidaka, T. 1977. Adaptation and speciation in the fall webworm. Kodansha, Tokyo, Japan.

Hildahl, V. and Reeks, W.A. 1960. Outbreaks of the forest tent caterpillar Malacosoma disstria Hbn. and their effects on stands of trembling aspen in Manitoba and Saskatchewan. The Canadian Entomologist, 92: 199-209.

Holling, C.S. 1959. The components of predation as revealed by a study of small-mammal predation of the European pine sawfly. The Canadian Entomologist, 91: 293-320.

Hunter, A.F. 1991. Traits that distinguish outbreaking and nonoutbreaking Macrolepidoptera feeding on northern hardwood trees. Oikos, 60: 275-282.

Hunter, A.F. 1995. Population regulations: old arguments and a new synthesis. In Population dynamics: new approaches and synthesis. Edited by N. Cappuccino and P.W. Price. Academic Press, San Diego, California, United States of America. Pp. 19-37.

Ives, W.G.H. 1963. Effects of defoliation on survival of larvae of the larch sawfly Pristiphora erichsonii (Htg.). The Canadian Entomologist, 95: 887-892.

Ives, W.G.H. 1973. Heat units and outbreaks of the forest tent caterpillar, Malacosoma disstria (Lepidoptera: Lasiocampidae). The Canadian Entomologist, 105: 529-543.

Ives, W.G.H. 1976. The dynamics of larch sawfly (Hymenoptera: Tenthredinidae) populations in southeastern Manitoba. The Canadian Entomologist, 108: 701-730. 
Ives, W.G.H. and Muldrew, J.A. 1984. Pristiphora erichsonii (Hartig), larch sawfly (Hymenoptera: Tenthredinidae). In Biological control programmes against insects and weeds in Canada: 1969-1980. Edited by J.S. Kelleher and M.A. Hulme. Commonwealth Agricultural Bureaux, Famham Royal, United Kingdom. Pp. 369-380.

James, P.M.A., Cooke, B., Brunet, B.M.T., Lumley, L.M., Sperling, F.A.H., Fortin, M.J., et al. 2014. Life-stage differences in spatial genetic structure in an irruptive forest insect: implications for dispersal and spatial synchrony. Molecular Ecology, 24: 296-309.

Jardon, Y., Filion, L., and Cloutier, C. 1994. Tree-ring evidence for endemicity of the larch sawfly in North America. Canadian Journal of Forest Research, 24: 742-747.

Jardon, Y., Morin, H., and Dutilleul, P. 2003. Périodicité et synchronisme des épidémies de la torteuse des bourgeons de l'épinette au Québec. Canadian Journal of Forest Research, 33: 1947-1961.

Koricheva, J., Klapwijk, M.J., and Bjökman, C. 2012. Life history and host plant use in defoliators and bark beetles: implications for populations dynamics. In Insect outbreaks revisted. Edited by P. Barbosa, D.K. Letourneau, and A.A. Agrawal. Princeton University Press, Princeton, New Jersey, United States of America. Pp. 177-196.

Krause, C. 1997. The use of dendrochronological material from buildings to get information about past spruce budworm outbreaks. Canadian Journal of Forest Research, 27: 69-75.

Krause, C. and Morin, H. 1999. Tree-ring patterns in stems and root systems of black spruce (Picea mariana) caused by spruce budworm. Canadian Journal of Forest Research, 29: 1583-1591.

Larsson, S., Bjökman, C., and Kidd, N.A.C. 1993. Outbreaks in diprionid sawflies: why some species and not others? In Sawfly life history adaptions to woody plants. Edited by M.R. Wagner and K.F. Raffa. Academic Press, Boca Raton, Florida, United States of America. Pp. 453-479.

Lejeune, R.R. 1955. Population ecology of the larch sawfly. The Canadian Entomologist, 87: 11-117.

Lemieux, C. and Filion, L. 2004. Tree-ring evidence for a combined influence of defoliators and extreme climatic events in the dynamics of high altitude balsam fir forest, Mount Mégantic, southern Quebec. Canadian Journal of Forest Research, 34: 1436-1443.

Liebhold, A. and Kamata, N. 2000. Are population cycles and spatial synchrony a universal characteristic of forest insect populations? Population Ecology, 42: 205-209.

Martineau, R. 1985. Insectes nuisibles des forêts de l'est du Canada. Rapport technique de foresterie 32F. Service canadien des forêts, Administration centrale, Ottawa, Ontario, Canada.

McLeod, J.M. 1970. The epidemiology of the Swaine jack pine sawfly, Neodiprion swainei Midd. Forestry Chronicle, 44: 14-20.
McLeod, J.M. 1972. The Swaine jack pine sawfly, Neodiprion swainei, life system: evaluating the longterm effects of insecticide application in Quebec. Environmental Entomology, 1: 371-381.

Moreau, G. 2004. The influence of forest management on defoliator populations: a case study with Neodiprion abietis in precommercially thinned and natural forest stands. Dissertation. University of New Brunswick, Fredericton, New Brunswick, Canada.

Moreau, G. 2006. Past and present outbreaks of the balsam fir sawfly in western Newfoundland: an analytical review. Forest Ecology and Management, 221: 215-219.

Moreau, G., Eveleigh, E.S., Lucarotti, C.J., and Quiring, D.T. 2006a. Stage-specific responses to ecosystem alteration in an eruptive herbivorous insect. Journal of Applied Ecology, 43: 28-34.

Moreau, G., Eveleigh, E.S., Lucarotti, C.J., and Quiring, D.T. 2006b. Ecosystem alteration modifies the relative strengths of bottom-up and top-down forces in a herbivore population. Journal of Animal Ecology, 75: 853-861.

Moreau, G., Lucarotti, C.J., Kettela, E.G., Thurston, G.S., Holmes, S., Weaver, C., et al. 2005. Aerial application of nucleopolyhedrovirus induces decline in increasing and peaking populations of Neodiprion abietis. Biological Control, 33: 65-73.

Moreau, G. and Quiring, D.T. 2011. Stand structure interacts with previous defoliation to influence herbivore fitness. Forest Ecology and Management, 262: $1567-1575$.

Morin, H. and Laprise, D. 1990. Histoire récent des épidémies de la tordeuse des bourgeons de l'épinette au nord du lac Saint-Jean (Québec): une analyse dendrochronologique. Canadian Journal of Forest Research, 20: 1-8.

Morin, H., Laprise, D., and Bergeron, Y. 1993. Chronology of spruce budworm outbreaks near Lake Duparquet, Abitibi Region, Quebec. Canadian Journal of Forest Research, 23: 1497-1506.

Morris, R.F. 1959. Single-factor analysis in population dynamics. Ecology, 40: 580-588.

Morris, R.F. 1963a. The dynamics of epidemic spruce budworm populations. Memoirs of the Entomological Society of Canada, 95: 1-12.

Morris, R.F. 1963b. The effect of predator age and prey defense on the functional response of Podisus maculiventris Say to the density of Hyphantria cunea Drury. The Canadian Entomologist, 95: 1009-1020.

Morris, R.F. 1964. The value of historical data in population research, with particular reference to Hyphantria cunea Drury. The Canadian Entomologist, 96: 356-368.

Morris, R.F. 1971. The influence of land use and vegetation on the population density of Hyphantria cunea. The Canadian Entomologist, 103: 1525-1536.

Morris, R.F. 1972a. Fecundity and colony size in natural populations of Hyphantria cunea. The Canadian Entomologist, 104: 399-409. 
Morris, R.F. 1972b. Predation by insects and spiders inhabiting colonial webs of Hyphantria cunea. The Canadian Entomologist, 104: 1197-1207.

Morris, R.F. 1976a. Relation of mortality caused by parasites to the population density of Hyphantria cunea. The Canadian Entomologist, 108: 12911294.

Morris, R.F. 1976b. Influence of genetic changes and other variables on encapsulation of parasites of Hyphantria cunea. The Canadian Entomologist, 108: 673-684.

Morris, R.F. 1976c. Relation of parasite attack to the colonial habit of Hyphantria cunea. The Canadian Entomologist, 108: 833-836.

Morris, R.F. 1976d. Hyperparasitism in populations of Hyphantria cunea. The Canadian Entomologist, 108: 685-687.

Morris, R.F. and Fulton, W.C. 1970a. Heritability of diapause intensity in Hyphantria cunea and correlated fitness responses. The Canadian Entomologist, 102: 927-938.

Morris, R.F. and Fulton, W.C. 1970b. Models for the development and survival of Hyphantria cunea in relation to temperature and humidity. Memoirs of the Entomological Society of Canada, 102: 927-938.

Morris, R.F. and Miller, C.A. 1954. The development of life tables for the spruce budworm. Canadian Journal of Zoology, 32: 283-301.

Myers, J.H. 1998. Synchrony in outbreaks of forest Lepidoptera: a possible example of the Moran effect. Ecology, 73: 1111-1117.

Myers, J.H. 2000. Population fluctuations of the western tent caterpillar in southwestern British Columbia. Population Ecology, 42: 231-241.

Myers, J.H. and Rothman, L.D. 1995. Field experiments to study regulation of fluctuating populations. In Population dynamics: new approaches and synthesis. Edited by N. Cappuccino and P.W. Price. Academic Press, San Diego, California, United States of America. Pp. 229-250.

Nairn, L.D., Reeks, W.A., Webb, F.E., and Hildahl, V. 1962. History of larch sawfly outbreaks and their effect on tamarack stands in Manitoba and Saskatchewan. The Canadian Entomologist, 94: 242-254.

Nealis, V.G. 2015. Comparative ecology of coniferfeeding spruce budworms (Lepidoptera: Tortricidae) The Canadian Entomologist, doi:10.4039/tce. 2015.15.

Neilson, M.M. and Elgee, D.E. 1968. The method and role of vertical transmission of a nucleopolyhedrosis virus in the European spruce sawfly, Diprion hercyniae. Journal of Invertebrate Pathology, 12: 132-139.

Neilson, M.M. and Morris, R.F. 1964. The regulation of European spruce sawfly numbers in the Maritimes provinces of Canada from 1937 to 1963. The Canadian Entomologist, 96: 773-784.
Nishimura, P.H. and Laroque, C.P. 2010. Tree-ring evidence of larch sawfly outbreaks in western Labrador, Canada. Canadian Journal of Forest Research, 40: 1542-1549.

Ostaff, D.P., Piene, H., Quiring, D.T., Moreau, G., Farrell, J.C.G., and Scarr, T. 2006. Influence of pre-commercial thinning of balsam fir on defoliation by the balsam fir sawfly. Forest Ecology and Management, 223: 342-348.

Ostaff, D.P. and Quiring, D.T. 2000. Population trends of a specialist herbivore, the spruce bud moth, in young white spruce stands. The Canadian Entomologist, 132: 825-842.

Parish, R. and Antos, J.A. 2002. Dynamics of an oldgrowth, fire-initiated, subalpine forest in southern interior British Columbia: tree-ring reconstruction of 2 year cycle spruce budworm outbreaks. Canadian Journal of Forest Research, 32: 1947-1960.

Price, P.W. 1997. Insect ecology, 3rd edition. Wiley, New York, New York, United States of America.

Price, P.W., Roininen, H., and Ohgushi, T. 2005. Adaptive radiation into ecological niches with eruptive dynamics: a comparison of tenthredinid and diprionid sawflies. Journal of Animal Ecology, 74: 397-408.

Pureswaran, D.S., De Grandpré, L., Paré, D., Taylor, A., Barrette, M., Morin, H., et al. 2015. Climate-induced changes in host tree-insect phenology may drive ecological state-shift in boreal forests. Ecology, 96: 1480-1491.

Reeks, W.A. 1953. The establishment of introduced parasites of the European spruce sawfly, Gilpinia hercyniae (Htg.) in eastern Canada. Canadian Journal of Agricultural Science, 33: 405-429.

Régnière, J., Deslisle, J., Pureswaran, D.S., and Trudel, R. 2012. Mate-finding allee effect in spruce budworm population dynamics. Entomologia Experimentalis et Applicata, 146: 112-122.

Régnière, J. and Nealis, V.G. 2007. Ecological mechanisms of population change during outbreaks of the spruce budworm. Ecological Entomology, 32: 461-477.

Roland, J. 1988. Decline of winter moth populations in the North America: direct versus indirect effect of introduced parasites. Journal of Animal Ecology, 57: 523-531.

Roland, J. 1993. Large-scale forest fragmentation increases the duration of forest tent caterpillar outbreaks. Oecologia, 93: 25-30.

Roland, J. 1994. After the decline: what maintains low winter moth density after successful biological control? Journal of Animal Ecology, 63: 392-398.

Roland, J. 2005. Are the "seeds" of spatial variation in the cycles dynamics apparent in spatially-replicated short time-series? An example from the forest tent caterpillar. Annales Zoologici Fennici, 42: 1175-1178.

Roland, J. and Kaupp, W. 1995. Reduced transmission of forest tent caterpillar (Lepidoptera: Lasiocampidae) nulear polyhedrosis virus at the forest edge. Environmental Entomology, 24: 1175-1178. 
Roland, J., Mackey, B., and Cooke, B. 1998. Effects of climate and forest structure on duration of forest tent caterpillar outbreaks across central Ontario, Canada. The Canadian Entomologist, 130: 703-714.

Roland, J. and Taylor, P.D. 1997. Insect parasitoid species respond to forest structure at different spatial scales. Nature, 386: 710-713.

Ross, H.H. 1955. The taxonomy and evolution of the sawfly genus Neodiprion. Forest Science, 1: 196-209.

Roth, D., Roland, J., and Roslin, T. 2006. Parasitoids on the loose: experimental lack of support of the parasitoid movement hypothesis. Oikos, 115: 277-285.

Rothman, L. and Roland, J. 1998. Forest fragmentation and colony performance of forest tent caterpillar. Ecography, 21: 383-391.

Royama, T. 1984. Population dynamics of the spruce budworm, Choristoneura fumiferana. Ecological Monographs, 54: 429-462.

Royama, T. 1992. Analytical population dynamics. Chapman \& Hall, London, United Kingdom.

Royama, T. 1996. A fundamental problem with key factor analysis. Ecology, 77: 87-93.

Royama, T., MacKinnon, W.E., Kettela, E.G., Carter, N.E., and Hartling, L.K. 2005. Analysis of spruce budworm outbreak cycles in New Brunswick, Canada, since 1952. Ecology, 86: 1212-1224.

Shepherd, R.F., Bennett, D.D., Dale, J.W., Tunnock, S., Dolph, R.E., and Their, R.W. 1988. Evidence of synchronized cycles in outbreak patterns of Douglas-fir tussock moth, Orgyia pseudotsugata (McDunnough) (Lepidoptera: Lymantriidae). Memoirs of the Entomological Society of Canada, 120: $107-121$.

Shepherd, R.F. and Gray, T.G. 2001. Comparative rates of density change in declining populations of the blackheaded budworm Acleris gloverana (Lepidoptera: Tortricidae) among different sites on Vancouver Island. Environmental Entomology, 30: 883-891.

Simard, I., Morin, H., and Lavoie, C. 2006. A millennial-scale reconstruction of spruce budworm abundance in Saguenay, Quebec, Canada. The Holocene, 16: 31-37.

Sippell, L. 1962. Outbreaks of the forest tent caterpillar, Malacosoma disstria Hbn., a periodic defoliator of broad-leaved trees in Ontario. The Canadian Entomologist, 94: 408-416.

Smith, A.M., Eveleigh, E.S., McCann, K.S., Merilo, M.T., McCarthy, P.C., and Van Rooyen, K.I. 2011. Barcoding a quantified food web: crypsis, concepts, ecology and hypotheses. Public Library of Science One, 6: e14424.

Sonia, S., Morin, H., and Krause, C. 2011. Long-term spruce budworm outbreak dynamics reconstructed from subfossil trees. Journal of Quaternary Science, 26: 734-738.

Stairs, G.R. 1966. Transmission of virus in tent caterpillar populations. The Canadian Entomologist, 98: $1100-1104$.
Sutton, A. and Tardif, J.C. 2007. Dendrochronological reconstruction of forest tent caterpillar outbreaks in time and space, western Manitoba, Canada. Canadian Journal of Forest Research, 37: 1643-1657.

Tothill, J.D. 1922. The natural control of the fall webworm (Hyphantria cunea Drury) in Canada, together with an account of its several parasites. Canadian Department of Agriculture Bulletin, 3: 1-107.

Turchin, P. 1995. Population regulation: old arguments and a new synthesis. In Population dynamics: new approaches and synthesis. Edited by N. Cappuccino and P.W. Price. Academic Press, San Diego, California, United States of America. Pp. 19-41.

Turnock, W.J. and Muldrew, J.A. 1971. Pristiphora erichsonii (Htg.), larch sawfly, (Hymenoptera: Tenthredinidae). In Biological control programmes against insects and weeds in Canada, 1959-1968. Commonwealth Institute of Biological Control. Technical Communication, 4: 175-194.

Turnock, W.J. and Muldrew, J.A. 1972. Characteristics of Bessa harveyi (Diptera: Tachinidae) suggesting the historic introduction of the larch sawfly to North America. Manitoba Entomologist, 6: 49-53.

Varley, G.G. and Gradwell, G.R. 1968. Population models for the winter moth. In Insect abundance. Edited by T.R.E. Southwood. Blackwell Scientific, Oxford, United Kingdom. Pp. 132-142.

Volney, W.J.A. 1988. Analysis of historic jack pine budworm outbreaks in the prairie provinces of Canada. Canadian Journal of Forest Research, 18: 1152-1158.

Wallace, D.R. and Cunningham, J.C. 1995. Diprionid sawflies. In Forest insect pests in Canada. Edited by J.A. Armstrong and W.G.H. Ives. Natural Resources Canada, Canadian Forest Service, Ottawa, Ontario, Canada. Pp. 193-232.

Wellington, W.G. 1952. Air-mass climatology of Ontario north of Lake Huron and Lake Superior before outbreaks of the spruce budworm, Choristoneura fumiferana (Clem.) and the forest tent caterpillar, Malacosoma disstria Hbn. (Lepidoptera: Tortricidae; Lasiocampidae). Canadian Journal of Zoology, 30: 114-127.

Williams, S.W. and Liebhold, A.M. 2000. Spatial scale and the detection of density dependence in spruce budworm outbreaks in eastern North America. Oceologia, 124: 544-552.

Witter, J.A. and Kulman, H.M. 1972. Mortality factors affecting egg of the forest tent caterpillar, Malacosoma disstria (Lepidoptera: Lasiocampidae). The Canadian Entomologist, 104: 705-710.

Wood, D.M., Parry, D., Yanaia, R.D., and Pitel, N.E. 2010. Forest fragmentation and duration of forest tent caterpillar (Malacosoma disstria Hübner) outbreaks in northern hardwood forests. Forest Ecology and Management, 260: 1193-1197.

Zhang, Q.B. and Alfaro, R.I. 2002. Periodicity of two-year cycle spruce budworm outbreaks in central British Columbia: a dendro-ecological analysis. Forest Science, 48: 722-731. 